\title{
Negociação de sinal de TV por assinatura
}

\author{
Conselho Administrativo de Defesa Econômica (Cade)
}

Ato de Concentração no 08700.006723/2015-21

Requerentes: TV SBT Canal 4 de São Paulo ("SBT"), Rádio e Televisão

Record S.A. ("Record") e TV Ômega Ltda. (“Rede TV!").

\section{Terceiros}

Interessados: Sky Brasil Serviços Ltda. ("Sky"), Claro S.A. ("Claro-NET",

"Claro" ou "NET"), Associação Brasileira de Televisão por

Assinatura ("ABTA")

Advogados: Tito Amaral de Andrade, Maria Eugênia Novis e outros;

Leonor Cordovil, Carolina Saito da Costa e outros; Guilherme

Ribas, Tomás Paiva e outros; Leonardo Maniglia Duarte,

Rodrigo Alves dos Santos e outros

Relatora: Conselheira Cristiane Alkmin Junqueira Schmidt

Voto-vista: Conselheiro Alexandre Cordeiro

EMENTA: Ato de Concentração. Operação realizada no Brasil. Procedimento Ordinário. Joint Venture de negociação de sinal digital de programação de televisão aberta para distribuidora de televisão por assinatura. Subsunção ao art. 88 da Lei $n^{0}$ 12.529/2011. Mercado relevante na dimensão produto: sinal de TV aberta para operadora de TV por assinatura. Mercado relevante na dimensão geográfica: Brasil. Concentração horizontal. Ausência de probabilidade de entrada, importação ou rivalidade. Poder compensatório na compra. Decisão da Superintendência-Geral favorável à aprovação sem restrições. Subida por recurso. Voto da Relatora pela reprovação. Aprovação com restrições. 
Palavras-chave: ato de concentração, sinal de televisão digital, radiodifusão, televisão por assinatura, joint venture de venda.

\section{Voto-vista}

\section{Versão pública}

\section{Relatório}

1. Trata-se de ato de concentração que reporta intenção de constituição, pelas requerentes (SBT, Record e Rede TV!), de uma sociedade empresária descrita comojoint venture edestinada a atuar, principalmente, nolicenciamento do sinal digital de seus canais de programação para prestadoras de serviços de televisão por assinatura.

2. Em 1ํ de outubro de 2015 a Superintendência-Geral do CADE ("SG") emitiu Parecer de aprovação do ato de concentração sem restrições (SEI n ${ }^{0}$ 0115549 e 0115572). Entendeu a SG que no cenário mais restritivo de definição de mercado relevante ${ }^{1}$ a participação conjunta de market share alcançaria 35\%, porém isto não implicaria em probabilidade de exercício de poder de mercado. Isto porque o poder seria limitado a partir das seguintes características: (i) as demandantes de sinal possuiriam grande força de barganha na compra, pois o mercado brasileiro de operadoras de televisão por assinatura seria bastante concentrado, com 83\% dos assinantes na carteira de clientes de apenas duas ofertantes, Net e Sky; (ii) a televisão aberta seria um mercado de dois lados, unindo publicidade e audiência, o que implicaria em dependência da fornecedora do sinal em relação à veiculação dele perante os assinantes de TV - menor chance de exibição implicaria em menores receitas publicitárias. Consideraram também que, mesmo que houvesse exercício de poder de mercado por parte das requerentes e que algumas operadoras não conseguissem suportar, o consumidor não seria prejudicado, porque teria acesso gratuito a sinal de alta qualidade por meio das transmissões de TV digital terrestre, que já teria cobertura relevante.

1 Fornecimento de sinal de canal de TV aberta para operadora de televisão por assinatura. No cenário menos restritivo todos os canais para TV por assinatura seriam tratados como substitutos e a concentração resultante da operação seria de aproximadamente $17 \%$. 
3. Designada com Relatora (SEI 0123469), a Conselheira Cristiane Alkmin Junqueira Schmidt realizou extensa instrução suplementar, solicitando das requerentes apresentação de formulário aplicável a rito ordinário de apreciação, bem como oficiando e realizando reuniões com diversos agentes de mercado: outros programadores, operadoras de TV por assinatura, associações e agências reguladoras - Anatel e Ancine.

4. Em 24 de fevereiro de 2016, na 80ª Sessão Ordinária de Julgamento, a Relatora submeteu a operação ao Plenário deste CADE e emitiu voto pela reprovação (SEI 0171871). Resumidamente, entendeu a Conselheira que:

a) o ato não poderia ser julgado de modo simplificado, segundo rito sumário, vez que a sociedade notificada não se qualificaria como joint venture clássica (para fins do art. 8o, I, da Resolução CADE $\mathrm{n}^{\mathrm{o}}$ 2/2012); além disso, haveria sobreposição horizontal e a participação de mercado conjunta das requerentes seria maior que $20 \%$ e;

b) O Guia da $F T C^{2}$ de análise de cooperação entre competidores e o livro da American Bar Association informariam que casos de joint ventures devem passar por escrutínio minucioso do órgão antitruste. A geração de eficiências seria uma condição necessária para a aprovação da operação em casos de joint ventures que implicassem em concentração horizontal ou vertical;

c) A dimensão produto do mercado relevante seria transmissão de conteúdo/programação linear da TV aberta para a operadora de TV paga. Canais de outros gêneros que não TV aberta não seriam incluídos no mesmo mercado porque, do ponto de vista da percepção do consumidor, haveria mais complementaridade do que substitutibilidade entre os canais das TVs abertas e os canais das programadoras de TVs pagas;

d) A dimensão geográfica do mercado relevante seria nacional, vez que seria o âmbito em que ocorreria, em regra, a negociação e a precificação do sinal;

e) Considerando essa definição de mercado relevante, haveria posição dominante, já que a soma da participação de mercado das três requerentes alcançaria 35\% (os outros agentes com participação relevante seriam TV Globo, com aproximadamente 58\%, TV Band com 7\% e TV Cultura com menos de $1 \%$ );

2 Federal Trade Commission. 
f) Por questões regulatórias a transmissão do conteúdo/programação linear de uma TV aberta brasileira seria nacional, de modo que a possibilidade de importação não teria potencial disciplinador no caso do exercício do poder de mercado incrementado;

g) A competição no mercado relevante afetado se daria por audiência e não por preço, de forma que a joint venture que se planeja constituir seria ineficaz para retirar audiência da líder de mercado, pois não teria como objeto principal juntar esforços para introduzir novas opções ao telespectador, veicular programação em outras plataformas ou focar no mercado de canais pagos;

h) Por não ter por objeto principal incrementar competição, a rivalidade não seria fonte de potencial disciplinador no caso do exercício do aumentado poder de mercado;

i) A entrada de uma nova radiodifusora no mercado seria improvável, intempestiva e insuficiente em função de elevadas barreiras financeiras, físicas (escassez de espectro eletromagnético) e regulatórias (obtenção de outorga pelo Executivo e deliberação do Congresso Nacional). Última entrada relevante teria sido a Rede TV! em 1999;

j) Sinais de TVs abertas não constituiriam facilidades essenciais para o desenvolvimento da atividade de venda de assinaturas em serviços de acesso condicionado (no mesmo sentido, citou voto do Cons. Celso Campilongo no PA 53500.000359/1999);

k) Haveria incentivos para a Newco impor preços supracompetitivos para as operadoras de televisão por assinatura, a despeito da característica da radiodifusão privada como mercado de dois lados (emissora serve como plataforma que pode captar diferentes receitas decorrentes da integração entre telespectador e anunciantes);

1) O primeiro incentivo para preços supracompetitivos seria decorrente do fato de a receita publicitária da radiodifusora ser independente da janela de veiculação, de modo que a perda de telespectadores assinantes seria facilmente compensada pela migração destes para o serviço via televisão digital terrestre, mantido diretamente pelas próprias geradoras da programação;

m) $\mathrm{O}$ segundo elemento que indicaria probabilidade de exercício de poder de mercado seria que este é exatamente a razão de ser da joint venture, de modo que se fosse absolutamente impossível concretizá-lo as requerentes sequer planejariam; 
n) O provável aumento de preços do sinal de programação redundaria em aumento de preço das assinaturas de televisão paga, pois o mercado dos produtores deste serviço não SERIA competitivo (operadoras seriam fazedoras e não tomadoras de preço) e os consumidores destes serviços seriam menos sensíveis a aumento de preço, por serem de classe média-alta;

o) Não haveria eficiências certas, específicas e quantificáveis que permitissem aprovar a operação;

p) A tese da eficiência gerada por criação de poder compensatório não se aplicaria ao caso concreto e teria pouco respaldo em literatura econômica e prática antitruste internacional.

5. Além de votar pela reprovação, a Conselheira fez recomendações à Anatel e à Ancine para que:

a) Avalie regras de verticalização entre TVs abertas líderes de audiência e operadoras de TV por assinatura líderes de mercado, visando desfazer incentivo a práticas de fechamento;

b) Atualize o marco regulatório atual (retransmission consent/must carry) para fins de elaborar lista de geradoras e retransmissoras que podem solicitar veiculação de sinais pelas operadoras de TV por assinatura;

c) Verifique, juntamente com a Ancine, se há tratamento não isonômico ou discriminatório para operadoras de televisão por assinatura com baixa participação de mercado e para novos entrantes, eventualmente até outorgando a estas operadoras benefício de must offer por parte das radiodifusoras;

d) Avalie, juntamente com a Ancine, se regras de não discriminação e isonomia estão estimulando entradas no mercado de operadores de televisão por assinatura e estimulando a franja competitiva;

e) Explicite, juntamente com a Ancine, as linhas de contraste que definem alcance regulatório de cada uma destas agências.

6. À Superintendência-Geral do CADE recomendou que apure se há venda casada entre sinal aberto da TV Globo, líder de audiência, e os canais pagos comercializados pela Globosat, bem como que apure proporcionalidade entre preços pagos por pequenas e grandes operadoras de TV por assinatura, com fins de aferir isonomia e não discriminação.

7. Após o voto da Conselheira Relatora, pedi vista para complementar a visão exposta, apreciar melhor teses de eficiências, e, sendo o caso, encaminhar eventuais remédios para as preocupações concorrenciais exploradas no Voto da Relatora. 
8. Informo que é de 314 dias o prazo decorrido entre a notificação e esta Sessão de Julgamento.

\section{I.1. Das manifestações dos terceiros intervenientes}

9. O processo conta com a presença de três terceiros interessados habilitados (Sky, Claro-NET e ABTA). Os três foram os responsáveis pelo recurso da decisão da SG-CADE que precedeu a subida do processo ao Tribunal. Reiteradamente, todos se manifestam ao longo de todo processo no mesmo sentido: contra a operação por entender viciado o aspecto da sociedade que implica na negociação conjunta de direitos sobre os sinais de programação de canais de TV aberta concorrentes fornecidos para operadores de TV por assinatura.

10. Há ainda uma quarta peticionária, a Associação Neo TV - Neo TV. Embora a Neo TV não tenha se habilitado nos autos, intervém com frequência e representa interesse de pequenos operadores de televisão por assinatura, se considerada a base nacional de assinantes.

11. Quando indagadas de modo final acerca de aspectos gerais da operação e de remédios cabíveis e negociados para o ato de concentração, as terceiras expuseram as seguintes considerações preliminares e de mérito.

12. Claro-Net NET (SEI 0197563) se manifestou preliminarmente pelo acesso ao texto do Acordo em Controle de Negociações - ACC - então em negociação. Entendeu que, sem isso, ficaria prejudicado o devido processo legal. No mérito, reiterou ser pela reprovação da operação com base nos seguintes argumentos:

a) Não se pode analisar o ato de concentração como se fosse uma joint venture clássica, uma vez que as requerentes não se juntarão para produzir conjuntamente nova oferta de produtos.

b) O objeto da operação é nitidamente anticompetitivo e, se aprovada, produzirá efeitos análogos a um cartel. As requerentes são e continuarão sendo concorrentes e buscam isenção antitruste para coordenar vendas e impor para as operadoras de TV por assinatura a venda casada de sinal digital de seus canais de TV aberta. Isto implicaria em aumento artificial de poder de barganha e na prática de preços acima dos níveis competitivos.

c) Mesmo que se cometa o equívoco de analisar a operação como uma concentração tradicional, ela resultará em concentração elevada 
- superior a 30\% do mercado nacional de TVs abertas e muito provavelmente resultará em aumento de preços para os consumidores ou em elevação de barreiras à entrada, pois o mercado seria altamente concentrado e sem rivalidade efetiva.

d) As requerentes não teriam demonstrado eficiências que cumulassem as seguintes características: prováveis, verificáveis, específicas e que incrementassem bem-estar dos consumidores. Por terem ausentes tais qualidades, não preencheriam os requisitos do art. 88 , $\S 6^{\circ}$, da Lei no 12.529/2011.

13. A Sky também impugnou o devido processo pela falta de acesso prévio ao texto do ACC. Sobre o mérito do ato de concentração, sustentou que a operação deveria ser reprovada porque o arranjo da joint venture Newco, de negociação de sinais digitais de TV aberta em conjunto, implicaria na neutralização de rivalidade e na elevação de preços a patamares supracompetitivos. Sustentou que este também foi o fundamento pelo qual a Federal Communications Commission dos Estados Unidos ("FCC") teria proibido per se associações comerciais deste tipo, ao regular critérios para negociação de boa-fé, quando envolvesse quaisquer das quatro maiores radiodifusoras americanas classificadas segundo a audiência (SEI 0194759).

14. A ABTA, também contrária in totum à operação, considera que (SEI 0194735):

a) O objeto principal da Newco, licenciar canais abertos junto a operadoras de SeAC, é um ilícito per se - cartel -, vez que se trata de um acordo para fixação de preços e de não competição entre agentes de um mercado. Lateralmente, diz que a sociedade atentaria contra norma de vedação à concentração econômica na radiodifusão (Decreto-Lei no 236/1967).

b) Sendo analisada pela regra per se, a operação somente pode ser aprovada, mesmo que condicionada, se forem comprovados efeitos líquidos não negativos.

c) Com as características que tem, a operação tenderia a diminuir a concorrência entre as radiodifusoras, resultar na cobrança de preços abusivos que serão repassados aos consumidores de TV por assinatura, discriminar operadoras de DTH e a cabo e distorcer a relação entre emissoras cabeças-de-rede das Requerentes e as emissoras afiliadas.

15. A Neo TV, inicialmente contrária à operação, manifestou-se favoravelmente à adoção de uma condição específica para aprovação da operação, o compromisso de fornecimento gratuito e não oneroso de programação e 
SBT, Record e Rede TV! em favor de pequenas operadoras de televisão por assinatura (SEI 0194635). Entendem que a desproporção da força de barganha entre suas associadas e as requerentes é preexistente e apenas se agravará caso não haja o estabelecimento de obrigação deste tipo.

\section{Preliminar - ausência de prejuizo de contraditório em intervenção de terceiros}

16. Os argumentos de mérito trazidos pelos interessados serão tratados ao longo da fundamentação da decisão. Merece atenção preliminar, contudo, o argumento de que as terceiras Claro-NET, Sky e ABTA não teriam tido acesso à discussão dos remédios tidos por mim como adequados a este Ato de Concentração.

17. Embora não tenham tido acesso ao texto do ACC no período anterior à celebração do acordo, conforme é praxe neste CADE, suas manifestações revelaram a consciência exata dos termos das negociações. Por exemplo, a Claro-NET, na petição SEI nº 0196887, fez precisas considerações sobre os elementos fundamentais do remédio que adiante encaminho justificadamente para este ato de concentração: o novo balanceamento da importância dos objetos da Joint Venture de modo a expandir oferta, a assunção de compromissos de diferenciados de negociados conforme a capacidade de compra da operadora de SeAC e o estabelecimento de prazo de vigência para Joint Venture. As considerações não foram superficiais, ocuparam dez laudas, e expuseram de modo completo as razões pelas quais a peticionária entende inadequados os remédios (v. SEI no 0194936).

18. O contraditório também foi possível para a Sky, que apresentou até mesmo parecer de Consultoria econômica justificando por que entendia que não haveria remédios possíveis para a formação da joint venture em questão (SEI 0194759). Sobre os remédios específicos encaminhados ao final deste voto, os enunciou de modo perfeito e teceu críticas, demonstrando conhecimento acerca da negociação e também juízo de reprovação a respeito da aplicabilidade.

19. A especificidade e as considerações detalhadas que foram feitas por estas terceiras intervenientes revelam perfeito conhecimento dos elementos de negociação e exercício do direito de influir nas decisões, de modo que não se pode falar de violação ao devido processo legal. 
20. A negativa de acesso ao texto do ACC, por sua vez, teve fundamentos expostos no Despacho 6/2016/GAB6/CADE. Defendi a confidencialidade da negociação nos seguintes termos:

A negociação de ACC em curso contempla informações das requerentes protegidas por segredos de empresas, como planos de negócios, termos de sociedade e níveis de investimento. A preservação da restrição de acesso de terceiros a estas informações é instrumental ao princípio constitucional de proteção da livre-iniciativa e livre concorrência (art. 1ํ, IV e art. 170, caput, e incisos II e IV da CRFB/88).

Com efeito, casos como o atual são tão comuns nas circunstâncias de negociação de ACC que é corrente que se tratem de negociações confidenciais, feitas em audiência de acesso vedado a terceiros. O próprio Regimento Interno da autarquia prezêe expressamente no $\S 1^{\circ}$ do artigo 125 que proposta de Acordo de Controle de Concentrações deve ser autuada em apartado:

"Art. 125. O Cade poderá receber propostas de Acordo em Controle de Concentrações (ACC) desde o momento da notificação até 30 (trinta) dias após a impugnação pela Superintendência Geral, sem prejuizo da análise de mérito da operação.

$\S 1^{\circ}$ O ACC será autuado em apartado e apensado ao processo administrativo para análise de ato de concentração econômica."

Observe-se que, por certo, a autuação em apartado se refere a volume de acesso restrito ao CADE e às Requerentes, eis que os documentos de curso normal devem necessariamente ser encartados em volume comum, não apartado e público.

Ademais, o parágrafo 9 do mesmo artigo 125, que trata da publicação de versão pública do ACC, estabelece que é de cinco dias contados a partir da celebração o prazo para disponibilização no sítio do CADE de versão pública:

"§9ํ№ prazo de 5 (cinco) dias de sua celebração, versão pública do ACC será disponibilizada no sítio do Cade (www.cade.gov.br) durante o período de sua vigência."

Assim, entendo que este parágrafo complementa o primeiro, e evidencia, à luz dos preceitos constitucionais, a natureza preponderante da negociação do ACC antes de sua celebração.

21. Com estes argumentos, rejeito a inadequação do procedimento de negociação de remédios do Ato de Concentração tendo em vista que o 
efetivo do exercício do contraditório materializado neste processo evidencia concretização do direito ao devido processo legal em favor de terceiros economicamente afetados pela operação.

22. Passo, a seguir, às considerações de mérito do Ato de Concentração, tendo por contexto a instrução realizada e os argumentos até aqui trazidos pela Conselheira Relatora, na forma a seguir.

\section{Mérito}

\section{III.1. Elementos introdutórios}

23. Observo que as empresas requerentes são empresas privadas dedicadas à exploração comercial da radiodifusão. Com fins de demonstrar o contexto que entendo relevante para a avaliação dos riscos associados ao presente ato de concentração, apresento a seguir breves considerações introdutórias sobre a história e a estrutura dos mercados de radiodifusão e televisão por assinatura.

\section{III.1.7. O desenvolvimento da indústria da televisão}

24. O surgimento da indústria da radiodifusão, ramo de atividade no qual a televisão aberta se insere, remonta ao final da segunda guerra mundial, quando ex-combatentes dos Estados Unidos começaram a se utilizar da emissão e recepção de sinais radiofônicos para comunicações privadas. Até aquele momento a principal aplicação do rádio era para comunicações militares. $^{3}$

25. Ao longo do tempo foram se formando em torno de antenas transmissoras pequenas estações amadoras de produção de serviços destinados a entreter e informar a comunidade em que se inseriam. Da capacidade de a programação, o sequenciamento de programas, atrair audiência surgiu o

3 Tal como a Arpanet, que foi a rede militar de comunicação de computadores precursora da internet, a tecnologia militar de comunicação por rádio gerou externalidades em aplicações de uso civil. Todo o histórico aqui narrado tem por fonte livro This Business of Television. The Standard Guide to the Television Industry. 3 ed. BLUMENTHAL, Howard J.; GOODENOUGH, Oliver R. New York: Billboard Books, 2006. 
modelo de negócio que até hoje domina a radiodifusão comercial. Empresas interessadas em incrementar suas vendas começaram a comprar publicidade nas transmissões, fosse pela via de patrocínios a programas específicos ou por meio de tempo de inserção de anúncio no meio da programação.

26. Com o sucesso da utilização civil do rádio, Comitês foram formados para estabelecer padrões tecnológicos que permitissem a formação de redes integradas de transmissões de imagens e sons. ${ }^{4}$ A transmissão de conteúdo em televisão inicialmente replicou o mesmo modelo de negócio das transmissões de rádio. ${ }^{5}$ A semelhança aconteceu inclusive nos tipos de programas, repetidos até hoje, a despeito da variação de preferências ao longo do tempo: execução de músicas, coberturas de eventos esportivos, coberturas de eventos públicos, entrevistas, show de variedades e dramatização de histórias.

27. Os tempos de programação, que ocupavam apenas horários específicos do dia, foram se tornando mais longos à medida que os recursos publicitários se interessavam pela nova mídia. É de se notar aqui que as radiodifusoras desde o início se ocuparam em produzir atrações que comporiam a sua programação, como um meio de atrair anunciantes. ${ }^{6}$ A produção de conteúdo, contudo, nunca foi monopólio de qualquer deles: qualquer escrito, qualquer música, qualquer evento, qualquer manifestação artística ou intelectual, podia encontrar expressão no formato televisivo, com diferentes graus de custos de adaptação.

\section{III.1.2. A televisão por assinatura}

28. Paralelamente ao avanço da radiodifusão televisiva foram se formando empresas e comunidades em torno do serviço de televisão por cabo. Inicialmente a televisão por cabo era uma forma de distribuição empregada para transportar para regiões isoladas a programação da radiodifusão aberta presente nas grandes cidades dos Estados Unidos. ${ }^{7}$

4 Nos Estados Unidos foi o National Television System Committee - NTSC.

Que, por sua vez, já haviam copiado o modelo de negócio da imprensa escrita.

6 Inobstante, na década de 1970, a Federal Communications Commission editou regras de proibição de verticalização, tendo por finalidade estimular nos Estados Unidos um mercado de produção audiovisual independente. Finalidade era limitar poder econômico e fomentar diversidade de iniciativas e opiniões. As regras ficaram conhecidas com Fin-Syn Rules. Em 1995 estas regras foram eliminadas do sistema americano, o que abriu espaço para a formação dos grandes conglomerados de mídia.

7 https://www.ncta.com/who-we-are/our-story; http://www.pcta.com/about/history.php. Consulta em 12.04.2016. 
29. Nos anos 1970, contudo, começou a emergir um outro modelo de negócio baseado no uso da infraestrutura desta televisão por cabo. Este modelo indicava que o telespectador pagaria não apenas pela infraestrutura, mas também pelo conteúdo que pretendia assistir. Nascia a televisão por assinatura. O conteúdo tradicional da televisão por assinatura é a programação linear (sequência não alterável pelo consumidor) de um ou mais canais tematicamente especializados. A TV por assinatura inovava em relação ao modelo de negócio da radiodifusão por prestigiar fonte de receita não publicitária para financiamento das programações veiculadas.

30. A televisão por assinatura acontece como uma alteração no modelo de negócio desta indústria. Tradicionalmente a emissora de televisão presta serviço ao telespectador de modo gratuito e remunera a atividade mediante a cobrança por anúncios publicitários. ${ }^{8} \mathrm{Na}$ televisão por assinatura o telespectador passa a ser fonte direta de financiamento, pois somente tem acesso ao conteúdo transmitido mediante pagamento. É admitida a veiculação de anúncios, mas a maior parte da receita nos canais por assinatura normalmente advém das cobranças ao usuário.

\section{III.7.3. O SeAC}

31. No Brasil a televisão por assinatura atualmente tem por marco normativo a Lei $\mathrm{n}^{\mathrm{o}} 12.485 / 2011$, cujo serviço ganha o nome serviço de acesso condicionado - "SeAC" - ou comunicação audiovisual de acesso condicionado.

32. Segundo a Lei no 12.485/2011 o SeAC é o "serviço de telecomunicações de interesse coletivo prestado no regime privado, cuja recepção é condicionada à contratação remunerada por assinantes e destinada à distribuição de conteúdos audiovisuais na forma de pacotes, de canais nas modalidades avulsa de programação e avulsa de conteúdo programado e de canais de distribuição obrigatória, por meio de tecnologias, processos, meios eletrônicos e protocolos de comunicação quaisquer" (art. $\left.2^{\circ}, \mathrm{XXIII}\right)$.

33. A cadeia de valor do SeAC é composta por quatro figuras principais: a produtora de conteúdo, a programadora, a empacotadora e a distribuidora. 8 É uma fórmula consagrada de subsídio cruzado no mercado de dois lados. Mais recentemente foi
usada com sucesso para monetizar o serviço de buscas na web. 


\section{Cadeia de Valor do SeAC}

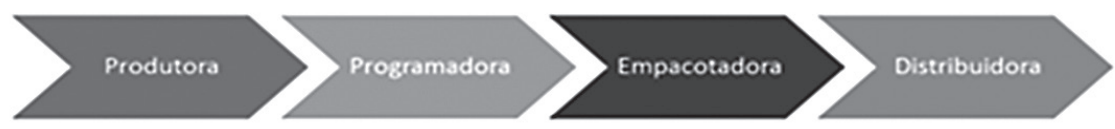

34. A produtora é a empresa que desenvolve "atividade de elaboração, composição, constituição ou criação de conteúdos audiovisuais em qualquer meio de suporte" (art. 2º ${ }^{\circ}$ XVII, da Lei no 12.485/2011).

35. Programadora é a empresa que seleciona, organiza e formata canais de programação, que por sua vez são arranjos de conteúdos audiovisuais organizados em sequência linear temporal com horários predeterminados (art. $2^{\circ}$, IV e XX da Lei $\left.\mathrm{n}^{\mathrm{o}} 12.485 / 2011\right)$.

36. A empacotadora é a empresa que agrupa canais de programação e oferta este grupo de canais às distribuidoras. Os canais de distribuição obrigatória, dentre os quais se incluem os analógicos de TV aberta (art. $2^{\circ}$, XI e XVI e art. 32, I, da Lei no $12.485 / 2011$ ), não são se a liberdade de empacotamento [sic]. Isto significa dizer que a sua forma de disposição e sequenciamento é prevista de modo rígido em lei, tendo em conta a maior eficácia na divulgação destes canais.

37. Cabe à distribuidora a "entrega, transmissão, veiculação, difusão ou provimento de pacotes ou conteúdos audiovisuais a assinantes por intermédio de meios eletrônicos quaisquer, próprios ou de terceiros" (art. $2^{\circ}, \mathrm{X}$ ). $\mathrm{O}$ consumidor final de SeAC é chamado assinante e é com a distribuidora que o assinante se relaciona. Neste voto tomamos como sinônimo de distribuidora as expressões "operadora de SeAC", "operadora de TV por assinatura" e "operadora de TV paga". 9

38. As operadoras de radiodifusão sonora e de sons e imagens estão sujeitas a legislação própria e por isso, em regra, excluídas do âmbito de incidência da Lei do SeAC (art. $1^{\circ}$, parágrafo único). ${ }^{10}$ Há dispositivos excepcionais direcionados a estes agentes, contudo. É exemplo de tal tipo de dispositivo o

9 O Regulamento Anatel n⿳0 581/2012 define a mesma figura como prestadora (de SeAC).

10 "Art. 1ํㅡsta Lei dispõe sobre a comunicação audiovisual de acesso condicionado.

Parágrafo único. Excluem-se do campo de aplicação desta Lei os serviços de radiodifusão sonora e de sons e imagens, ressalvados os dispositivos previstos nesta Lei que expressamente façam menção a esses serviços ou a suas prestadoras." 
que prevê a possibilidade de atuação da radiodifusão como fornecedora de programação digital para operadora de SeAC (art. 32, §12). ${ }^{11}$

39. A operadora de SeAC ébasicamente uma empresa de telecomunicações que disponibiliza uma infraestrutura de transporte de conteúdo audiovisual de uma base de distribuição até a localidade em que esteja o cliente. Para realizar este serviço, as operadoras adquirem conteúdo de programadores (ou licenciadores, no caso do video on demand) e usam vários tipos de tecnologia para enviá-lo à tela de exibição do assinante. No Brasil as tecnologias mais comuns são a TV a cabo e a transmissão via satélite (DTH).${ }^{12}$

40. A TV a cabo é uma tecnologia de SeAC indicada para localidades com alta densidade populacional, como centros urbanos. É caracterizada pela utilização de cabeamento para transporte de sinal até o destino. Atualmente dominam neste tipo de rede as modalidades FTTH (Fiber to the Home) e HFC (Hybrid Fiber Coax).

41. O HFC é uma que utiliza fibras ópticas para transporte a maiores distâncias e cabos metálicos para distribuição local. É o tipo de rede mais comum por transportar com integridade o sinal a grandes distâncias e possuir custo de instalação vantajoso.

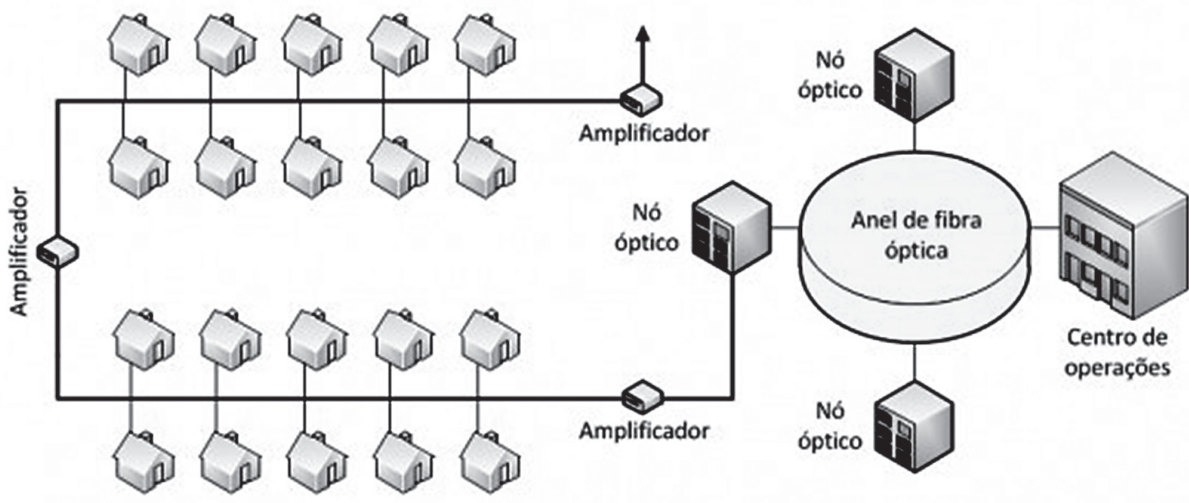

Fonte: http://adrenaline.uol.com.br/forum/threads/entendendo-as-redes-hfc-coaxial-tecnologiaequipamentos.406428/.

11 "A geradora local de radiodifusão de sons e imagens de caráter privado poderá, a seu critério, ofertar sua programação transmitida com tecnologia digital para as distribuidoras de forma isonômica e não discriminatória, nas condições comerciais pactuadas entre as partes e nos termos técnicos estabelecidos pela Anatel, ficando, na hipótese de pactuação, facultada à prestadora do serviço de acesso condicionado a descontinuidade da transmissão da programação com tecnologia analógica prevista no inciso I deste artigo."

12 Segundo dados da ABTA de junho de 2015, os percentuais de assinantes, por tecnologia, são de $60,3 \%$ para tecnologia DTH, 39,2\% para HTC e 0,5\% para FTTH. No entanto, há um número não relatado pela ABTA de assinantes que possuem serviços que utilizam outras tecnologias, como a IPTV. 
42. Na rede FTTH o transporte dos sinais é feito com maior predominância por cabos de fibra ótica, que possuem como vantagem uma maior largura de banda ${ }^{13}$ que as outras modalidades de cabos de rede. A estrutura serve para transporte de quaisquer tipos de dados, inclusive os nativos da internet. Em um mundo com demandas crescentes de capacidade para transporte de dados, essa característica faz com que esta tecnologia seja vista como a tendência das redes por cabo.

43. O tipo de FTTH varia de acordo com até que distância do destinatário final são utilizados apenas cabos de fibra ótica. De acordo com este critério são formas de FTTH o FTTB (Fiber to the Business ou Building ${ }^{14}$ ), FTTdp (Fiber to the Distribution Point ${ }^{15}$ ), FTTN (Fiber to the Neighborhood ${ }^{16}$ ) e outras denominações.

44. Esse tipo de rede também necessita da instalação prévia dos cabos e tem custo de instalação maior do que outras tecnologias. $\mathrm{O}$ ranking internacional de largura de banda costuma estar grandemente associado ao nível de penetração da tecnologia FTTH. ${ }^{17}$

45. Em todas as modalidades de TV a cabo, o cliente deve utilizar decodificador, que transforma os sinais recebidos em imagens e som para os televisores.

46. Ao lado das formas de televisão paga por cabo há a distribuição por satélite - DTH (Direct to Home $\left.{ }^{18}\right)$. Nesse tipo de tecnologia, o sinal é transmitido pelas fontes de programação (canais produtores de conteúdo) até as centrais de transmissão, que emitem sinais via satélite para as antenas receptoras instaladas na residência ou estabelecimento do assinante.

13 Largura de banda se refere à quantidade de dados que uma determinada rede consegue transmitir num determinado espaço de tempo.

14 Fibra para o Negócio ou a Construção.

15 Fibra para o Ponto de Distribuição.

16 Fibra para a Vizinhança. Tradução livre do gabinete.

17 Para dados globais de cobertura FTTH consultar http://www.ftthcouncil.eu/documents/Reports/ 2015/2015_RANKING_SLIDES.pdf.

18 Direto para o Lar. 


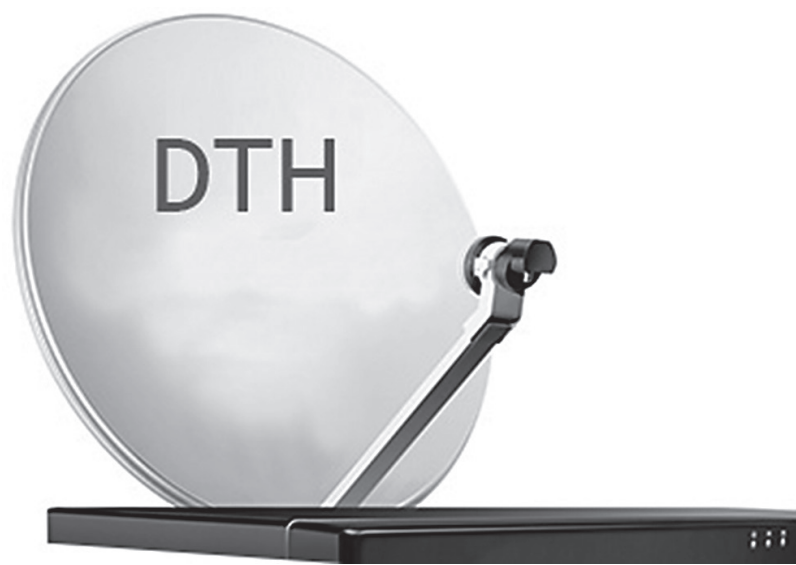

Fonte: http://www.pakistantoday.com.pk/2015/12/02/news/pemra-chief-postpones-dth-licenceauction-to-make-process-more-transparent/.

47. A vantagem no uso dessa tecnologia é maior facilidade de cobertura do serviço, uma vez que não é necessária infraestrutura local para receber o sinal, como acontece nas tecnologias via cabo. No entanto, há risco de interrupção e problemas nas transmissões devidos a condições climáticas. É o modo de TV paga mais comum no Brasil. Em termos de unidades federativas, apenas no Distrito Federal e em São Paulo o número de assinantes do cabo é superior ao de assinantes de DTH. ${ }^{19}$

48. Existem ainda outros modos de distribuição da TV por assinatura, quais sejam, a MMDS e a IPTV.

49. AMMDS (Multichanel Multipoint Distribution Service ${ }^{20}$ )éuma tecnologia que utiliza faixa de micro-ondas para transmitir os sinais dentro de uma área de prestação do serviço. É uma opção para áreas onde não é economicamente viável a instalação de cabeamento para transmissão, podendo ser também utilizada em centros urbanos com restrições para instalação de infraestrutura. Nas transmissões que utilizam essa técnica, a central da operadora transmite pelo ar o sinal para o assinante, que o recebe por meio de uma antena de microondas. O custo para a implantação de uma rede MMDS é relativamente baixo, porém no Brasil esse tipo de tecnologia é pouco utilizado e vem perdendo

19 http://sistemas.anatel.gov.br/saTVa/hotsites/conheca_brasil_saTVa/default.asp. Consulta em 12.04.2016.

20 Serviço de Distribuição de Sinais Multiponto Multicanais. 
espaço, pois ocupa a mesma faixa de frequência utilizada pelas operadoras de telefonia para disponibilização do serviço $4 \mathrm{G}$.

50. Por fim, o tipo mais recente de tecnologia comercialmente utilizada é a IPTV (Internet Protocol Television), ${ }^{21}$ serviço que disponibiliza sinais para aparelhos de televisão digital e outros meios através do protocolo de internet, conhecido como IP. A tecnologia é uma junção dos serviços de televisão com internet banda larga e consiste em transmitir sinais via internet, ao invés de outros meios como os destacados anteriormente. A IPTV necessita apenas de uma conexão de internet de pelo menos 4 megabits por segundo, e possui como vantagem permitir uma alta interatividade do assinante com o conteúdo disponibilizado. No entanto, ela é sujeita a variações de qualidade devido a problemas na conexão e lentidão nos serviços de interatividade.

\section{III.7.4. O mercado brasileiro de radiodifusão de sons e imagens (televisão aberta)}

51. O universo de competição efetiva e potencial em relação às requerentes depende das características do mercado de SeAC, mas também do mercado de televisão aberta. Por este motivo, registro as particularidades regulatórias e de funcionamento da TV aberta que merecem explicação.

52. O serviço de radiodifusão televisiva consiste na transmissão de sinal não codificado em determinada localidade. A princípio, todos os aparelhos da localidade têm capacidade de receber sinal tal sinal e assistir os conteúdos veiculados. No Brasil é considerado um serviço de competência da União, que o presta diretamente ou mediante concessão, autorização ou permissão (art. 21, XII, $a$, da CRFB/1988).

53. A justificativa pré-jurídica de definir a radiodifusão como um serviço público está associada a justificativas de segurança nacional e às externalidades positivas que sua prestação a contento pode propiciar. Conforme descrito em estudo feito pela Ancine e tomado por base para muitas passagens deste voto, é função social da radiodifusão: "permitir o acesso da população em geral a entretenimento, cultura, educação e informações, as quais devem refletir a pluralidade de pontos de vista de maneira que torne possível a formação de cidadãos com capacidade crítica. Por isso, diz-se que sua provisão encerra benefícios marginais à sociedade

21 Televisão por Protocolo de Internet. 
superiores aos seus custos. Ou seja, a TV aberta como forma de comunicação social gera externalidades positivas no consumo." 22

54. Como meio de potencializar as externalidades positivas da radiodifusão o Decreto $n^{\text {o }}$ 52.795/63 estabelece que a radiodifusão em geral deve ter finalidade educativa e cultural, mesmo em seus aspectos informativo e recreativo, e por isso devem ser considerados de interesse nacional. A exploração comercial "é permitida apenas na medida em que não prejudique esse interesse e aquela finalidade" (art. $3^{\circ}$ ).

55. A cadeia de valor da televisão aberta pode ser representada da seguinte forma:

\section{Cadeia de Valor da TV Aberta}

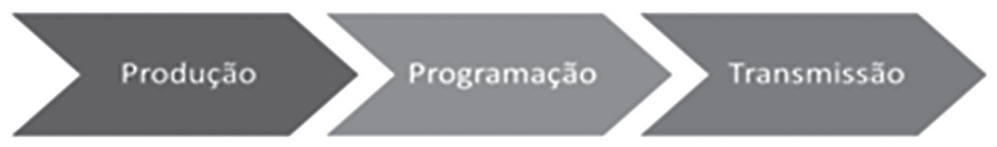

56. Tal como no SeAC, a produção é a atividade de elaboração, composição, constituição ou criação de conteúdos audiovisuais em qualquer meio de suporte. A feitura de um filme, série, telejornal ou programa de auditório são exemplos de atividades de produção.

57. A programação também tem definição idêntica à que ocorre no SeAC, consistindo na organização linear temporal de atrações/programas, que são unidades do conteúdo audiovisual.

58. Já a transmissão é a emissão de sinal de radiofrequência para captação direta pelo destinatário, é a entrega da programação ao telespectador que é feita por meio de equipamentos de tecnologia radioelétrica.

59. As outorgas para serviços de televisão aberta têm dimensão geográfica local e, se tiverem objetivo comercial, devem ser precedidas de licitação. ${ }^{23}$ Após a licitação, as outorgas do serviço dependem de ato do Poder Executivo

22 BRASIL, ANCINE, TV Aberta no Brasil: aspectos econômicos e estruturais. Observatório Brasileiro do Cinema e do Audiovisual - OCA - 2015, p. 16.

23 Art. 10 do Dec. 52.795/1963, com redação dada pelo Dec. 2.108/1996 c/c art. 13, §1 1 do mesmo decreto e art. 14, §2º , do Dec. 236/1967. Como a valorização está na faixa VHF, o mais comum é que líderes de rede constituam apenas 5 estações geradoras próprias. 
e de apreciação prévia do Congresso Nacional. ${ }^{24}$ Uma vez cumprido este rito, é possível adjudicação de faixa de frequência por ato da Anatel. ${ }^{25}$

60. Visando evitar a formação de oligopólios, cada emissora de televisão pode ter no máximo 10 estações radiodifusoras de som e imagem em todo o território nacional, sendo no máximo 5 em VHF e 2 por Estado. ${ }^{26} \mathrm{~A}$ limitação não se aplica a estações repetidoras e retransmissoras, definidas adiante.

61. O objetivo de evitar a formação de oligopólios se deve à vontade estatal de preservar a diversidade de conteúdos e opiniões em uma sociedade e é meritório. Contudo, é um desejo em conflito com as características econômicas do segmento, em que grandes economias de escala e escopo favorecem a formação de grandes conglomerados de mídia.

62. As economias de escala decorrem do fato de o conteúdo audiovisual de maior apelo comercial ter, normalmente, elevados custos de produção, porém custo de exibição significativamente menor. Isto implica custo marginal decrescente. Expor o produto audiovisual facilita o retorno do investimento. Maiores cadeias de transmissão de TV permitem tais audiências maiores, de forma que o custo fica diluído por um universo maior de consumidores até se atingir o ponto ótimo de produção.

63. As economias de escopo decorrem do fato de um produto audiovisual poder ser reformatado e reaproveitado de outra forma ao longo da programação do canal. Assim, o esforço jornalístico de cobertura de um evento esportivo pode gerar, além da transmissão ao vivo do evento, matérias jornalísticas a serem exibidas em telejornal de espectro geral ou especializado. Alguns talentos podem atuar em mais de um programa de uma emissora. Uma minissérie pode ser reeditada de modo a se transformar em um filme ou, para além da janela da TV aberta, ser comercializado como um DVD. O segmento produção audiovisual para TV aberta é prenhe de oportunidades de economias de escopo, os ativos pertinentes podem ser utilizados para produzir um ou mais produtos.

64. Por estas características, há uma tendência à concentração de mercado. No Brasil essa tendência assumiu forma das alianças de redes de televisão. As redes de televisão normalmente possuem a seguinte configuração:

24 Art. $223, \S \S 1^{\circ}$ e $4^{\circ}$ da CRFB/1988.

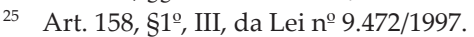

26 Art. 12, 2, do Decreto-Lei nº 236/1967 e art. 220, §5º, da CRFB/1988. 


\section{Configuração de Redes de Televisão no Brasil}

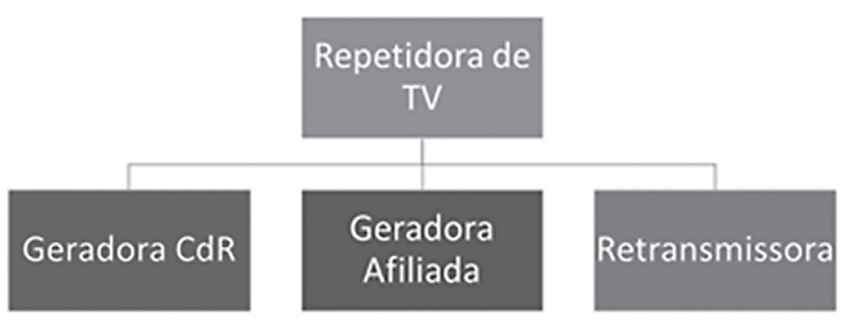

65. Segundo a legislação, geradora é uma categoria de estação de televisão que realiza emissões portadoras de programas que têm origem em seus próprios estúdios (art. 6º I, do Dec. 5.371/2005). A remissão a estúdios próprios não deve ser lida literalmente, mas apenas como a autorização e capacidade de produzir conteúdo audiovisual próprio.

66. Estação retransmissora é o conjunto de receptores e transmissores, incluindo equipamentos acessórios, capaz de captar sinais de sons e imagens e retransmiti-los, simultaneamente ou não, para recepção pelo público em geral (art. 6º III, do Dec. 5.371/2005).

67. Estação repetidora de televisão é o conjunto de receptores e transmissores, incluindo equipamentos acessórios, capaz de captar os sinais de sons e imagens oriundos de uma estação geradora, recebidos diretamente dessa geradora ou de outra repetidora, terrestre ou espacial, de forma a possibilitar seu transporte para outra repetidora, para uma retransmissora ou para outra geradora de televisão. Uma repetidora é sobretudo uma infraestrutura de transporte interno de sinal entre as estações-membro de uma rede de televisão própria ou com participação de terceiros. ${ }^{27}$

27 Há ainda a figura do SARC - Serviços Auxiliares de Radiodifusão e Correlatos, que são aqueles executados pelas concessionárias ou permissionárias de serviços de radiodifusão, para realizar reportagens externas, ligações entre estúdios e transmissores das estações, utilizando, inclusive, transceptores portáteis. São considerados correlatos ao serviço auxiliar de radiodifusão os enlaces-rádio destinados a apoiar a execução dos serviços de radiodifusão tais como comunicação de ordens internas, telecomando e telemedição. Um fenômeno interessante envolvendo transporte interno de sinal entre estações de uma rede de televisão é a utilização da chamada banda $C$ para transmitir sinal ao usuário final. A banda C é um espectro de frequência que serve para que se dê envio e recepção de sinal de programação entre as geradoras cabeças de rede, nacional ou regional, e suas respectivas afiliadas. Como as emissões são sinais codificados, é possível ter acesso às programações diretamente do reflexo satelital. 
68. A classificação que distingue geradora cabeça de rede e geradora afiliada não tem fonte na legislação, mas resulta de observação de arranjos privados que foram sendo construídos entre os agentes atuantes neste mercado no Brasil. Ser cabeça de rede significa ter liderança na formação da programação veiculada por um conjunto de radiodifusoras. A cabeça de rede licencia o direito de retransmissão de programação e o uso de sua marca pela afiliada na localidade em que esta tem atuação. Se observa também que afiliadas funcionem como lideranças intermediárias, pequenas cabeças de rede estaduais ou regionais.

69. As vantagens destes contratos privados para as partes envolvidas são: (i) para a cabeça de rede, expandir o universo de audiência de sua programação, facilitando acesso a escala que sustente a produção de conteúdo; (ii) para a afiliada, a veiculação a programação mais sofisticada do que a que teria se fosse produzir isoladamente e o acesso a remuneração superior, vez que a cabeça de rede repassa parte das receitas publicitárias decorrentes de contratos de campanhas nacionais, que são significativamente mais caros do que os contratos locais de anúncios publicitários.

70. Visando incentivar alguma regionalização, a legislação exige que pelo menos 5\% da programação de uma entidade que se qualifique como geradora seja produzida internamente e utilizada para serviço noticioso. ${ }^{28}$

71. Para a defesa da concorrência, um efeito negativo da formação de redes de televisão no mercado é limitar a variedade de conteúdo ofertado; tem-se menos programação do que haveria se cada geradora fosse diretamente responsável pela maior parte dos conteúdos que exigem. A concorrência entre programações de televisão aberta se dá basicamente entre as cabeças de rede nacionais. As três requerentes neste processo fornecem programação para geradoras afiliadas e retransmissoras em todo o território do Brasil, de modo que se qualificam como cabeças de rede nacionais.

72. Segundo levantamento da Anatel feito com a finalidade de definir obrigações de must carry, são 14 as redes nacionais de televisão com presença significativa ao longo do território nacional. ${ }^{29}$ A assimetria entre os agentes, porém, é grande, de modo que o universo de possíveis rivais é bem menor. Por estas características, é um mercado que pode ser caracterizado como um oligopólio competitivo.

28 Art. 38, $h$, da Lei no 4.117/1962.

29 Ato no 5.607/2012. Redes com presença nacional, segundo o nome fantasia, são: MTV Brasil, MIX TV, Canção Nova, Rádio e TV Aparecida, Globo, Band, CNT, Record, rede Mulher, SBT, rede Brasil, rede Internacional de Televisão, rede Vida, Rede TV! 


\section{III.2. Objetos da joint venture e mercados afetados}

73. Considerando que o mercado relevante afetado pela operação depende das ações que a empresa planeje desenvolver, registro que a sociedade notificada pretende ter por objeto as seguintes atividades: ${ }^{30}$

i. negociar conteúdo para televisão por assinatura. A atividade abrange licenciamento do sinal que contém a programação linear dos canais abertos mantidos por cada uma das sócias (SBT, Record e Rede TV!) e também o licenciamento das produções avulsas das sócias que tenham sido empregadas ou não na programação linear (novelas, séries, programas de entrevistas, cobertura de eventos esportivos etc.);

ii. produzir conjuntamente conteúdo audiovisual, incluindo os de natureza jornalística;

iii. assessorar as sócias de uma forma geral acerca de práticas de marketing e vendas;

iv. participar em outras sociedades.

74. Originariamente a sociedade pretendia ainda vender espaços para publicidade nos canais das sócias, porém este objeto foi suprimido no decorrer da tramitação do processo de controle de concentrações no CADE.

75. Do conjunto de atividades previstas, tem-se que são mercados de produtos e serviços afetados os seguintes:

(a) produção conjunta de conteúdo audiovisual no Brasil;

(b) licenciamento de conteúdo audiovisual avulso no Brasil;

(c) assessoria de marketing e vendas, exceto para TV aberta;

(d) licenciamento de programação linear de canais abertos para operadores de televisão por assinatura no Brasil.

76. Os mercados assim enunciados não correspondem com rigor a algum mercado relevante. Entender como funcionam, porém, serve para que não se declare preocupações concorrenciais apriorísticas em relação aos dois primeiros. Justifico tal posição a seguir.

30 No original: [acesso restrito ao CADE e Requerentes]. 


\section{III.2.1. Produção conjunta e licenciamento de conteúdo audiovisual no Brasil}

77. A produção de conteúdo audiovisual, nos termos da Lei n⿳ำ 12.485/2011, consiste em "fixar ou transmitir imagens, acompanhadas ou não de som, que tenha a finalidade de criar a impressão de movimento, independentemente dos processos de captação, do suporte utilizado inicial ou posteriormente para fixá-las ou transmiti-las, ou dos meios utilizados para sua veiculação, reprodução, transmissão ou difusão" (art. 2ํ, VII, da Lei no 12.485/2011). São exemplos da produção de conteúdo a gravação ou transmissão ao vivo de uma novela, programa de auditório, telejornal ou disputa esportiva.

78. O licenciamento é a negociação dos direitos de exploração comercial do produto audiovisual já existente. É firmado entre os detentores dos direitos patrimoniais sobre a obra (autores ou não) e o interessado em exibir o conteúdo a dada audiência.

79. Noto que historicamente a atratividade do conteúdo para o telespectador e para o assinante é o fator mais determinante de competição criativa no mercado de televisão, relacionado ao de produção de conteúdo. É neste campo que estão as maiores inovações desta indústria. A produção é tão decisiva que não se costuma licenciar um determinado produto para canais concorrentes que tenham a mínima chance de disputar a mesma audiência. Mesmo o conteúdo de produtores ou canais sem atuação no Brasil (logo, não concorrentes no mercado nacional), quando licenciados, costuma conter cláusula de exclusividade, de modo a que apenas o adquirente da licença tenha capacidade de auferir lucros decorrentes do interesse da audiência naquele dado conteúdo.

80. A produção conjunta de conteúdo audiovisual pelas radiodifusoras reunidas na joint venture não implicará, a princípio, no encerramento da produção individual pelas requerentes, de modo que se pode falar em nova oferta.

81. Além disso, há potencial de efeitos pró-competitivos da produção conjunta, na medida em que a reunião de equipes das requerentes, com diferentes talentos, tem potencial de complementaridade. Este potencial enseja aptidão para oferta diferenciada em relação ao que as sócias hoje produzem separadamente.

82. Uma visão alternativa, porém, poderia apontar que o vínculo societário entre Record, SBT e Rede TV! mudaria a estrutura de incentivos à rivalidade na produção entre estes agentes. Por esta visão, a joint venture poderia, 
por exemplo, ser usada para que os agentes se coordenassem, concentrassem investimento na sociedade em desfavor dos investimentos individuais, conhecessem previamente conteúdo planejado pelos rivais e ajustassem calendário de lançamentos.

83. Ainda assim, tal aspecto do ato de concentração não suscita preocupações concorrenciais. Com efeito, para além das requerentes, o mercado de produção de conteúdo audiovisual apresenta grande número de ofertantes, de variados portes, e aceita importação efetiva.

84. No Brasil a produção e o licenciamento de conteúdo audiovisual têm como expoente o grupo Globo, que controla emissora de TV de mesmo nome e que é apontada como a maior produtora de conteúdo audiovisual em língua portuguesa. ${ }^{31}$ A produção de conteúdo nacional é usada como vantagem competitiva da TV Globo, que tem notório sucesso na formatação de produção audiovisual que atende bem às preferências dos consumidores brasileiros. Como já destacado em Nota Técnica da Ancine e em Voto da Conselheira Relatora, a TV Globo coincide a liderança destacada em audiência com a liderança no percentual de conteúdo nacional na programação ("segundo Ancine (Nota Técnica $n^{\circ}$ 1/2016, Tabela 8, item 8.8), enquanto $77 \%$ da programação da Globo deriva de conteúdo nacional, 54\% é o percentual da SBT").

85. Além da TV Globo, há no Brasil uma grande gama de produtoras independentes. Apenas a Associação Brasileira de Produtoras Independentes de Televisão tem mais de seiscentos associados dedicados a compor suporte audiovisual com temáticas tão variadas quanto animação, documentários, musicais, publicidade, comédias, entre vários outros. ${ }^{32}$

86. Embora as produtoras independentes brasileiras sejam de médio ou pequeno porte, neste mercado não se pode ignorar a capacidade de estes agentes gerarem pressão concorrencial, especialmente em função de incentivos setoriais e arranjos de eficiência produtiva que as favorecem. Devido a estas características, mesmo radiodifusoras como a TV Record ou a TV SBT frequentemente optam por terceirizar produção de conteúdo mediante contratação destes agentes, a exemplo do que aconteceu com a novela Os Dez Mandamentos e o quiz show Um Contra Cem, produzidos pela Casablanca Filmes Ltda.

31 http://www.jb.com.br/heloisa-tolipan/noticias/2012/05/09/globo-sobe-em-ranking-e-torna-sesegunda-maior-emissora-do-mundo/.

32 http://abpiTV.com.br/site/abpiTV-comemora-a-marca-de-600-associadas-com-expansao-do-setor/ e http://abpiTV.com.br/site/associados/, consulta em 20.04.2016. 
87. Por fim, no campo das importações, os maiores produtores e licenciadores mundiais de conteúdo audiovisual são os conglomerados de mídia conhecidos como majors (atualmente The Big Six, "as seis grandes"): TimeWarner, 21st. Century Fox, Walt Disney Company, Sony Entertainment, UniversalNBC, Paramount-Viacom. Graças à estrutura de distribuição incomparável, possuem elevadas economias de escala. Assim se chamam porque são seis grupos com antecedentes ligados a dominância de mais de $80 \%$ da receita de bilheterias em cinemas na América do Norte. Ao longo dos anos as empresas primitivamente dedicadas exclusivamente a produções para cinema foram se unindo a grupos econômicos com atuações em outros tipos de mídia e outras janelas de exibição de conteúdo audiovisual (cinema, TV aberta, fechada e home video, inclusive com distribuição pela internet). ${ }^{33}$ São agentes de peso mundial na produção de filmes, séries para televisão, desenhos animados, documentários, reality shows e programas de culinária. Em menor grau, devido a barreiras culturais maiores, podem fornecer também atrações em cobertura esportiva e jornalística. Produtores independentes estrangeiros, especialmente quando associados a estes grupos, também se inserem na cadeia produtiva e geram produtos de alto apelo. Certamente tais agentes têm capacidade de limitar em algum grau poder de mercado decorrente de associação entre as requerentes.

88. Estes os elementos, verifico que, mesmo sem definição rigorosa de mercado relevante, é possível concluir que a pretendida aliança entre as requerentes não possui aptidão para limitação de oferta em nível que gere mínima preocupação antitruste, isto porque elas enfrentam concorrência de grande número de players com desempenho comercial comparável ou superior.

33 Para market share dos estúdios em bilheteria em 2015:

$\begin{array}{llccc}\text { Posição } & \text { Distribuidora } & \begin{array}{l}\text { Market } \\ \text { Share }\end{array} & \begin{array}{c}\text { Receita Total } \\ \text { (US\$ milhões) }\end{array} & \begin{array}{c}\text { Filmes } \\ \text { Distribuídos }\end{array} \\ 1 & \text { NBC/Universal } & \mathbf{2 2 , 3 \%} & \$ 2,562.5 & 32 \\ 2 & \text { Disney } & \mathbf{1 9 , 8 \%} & \$ 2,280.2 & 11 \\ 3 & \text { Time Warner (WB/New Line) } & \mathbf{1 6 , 9 \%} & \$ 1,940.6 & 30 \\ 4 & \text { News Corporation (Fox) } & \mathbf{1 2 , 4 \%} & \$ 1,422.2 & 25 \\ 5 & \text { Sony } & \mathbf{8 , 9} \% & \$ 1,028.3 & 35 \\ 6 & \text { Viacom (Paramount) } & \mathbf{5 , 9} \% & \$ 674.7 & 12\end{array}$

Fonte: http://www.boxofficemojo.com/studio/?view=company\&view2=yearly\&yr=2015\&p=.htm. 


\section{III.2.2. Assessoria de marketing e vendas em geral}

89. A joint venture notificada planeja atuar com assessoria de marketing e vendas em geral. O marketing é a atividade pela qual se busca incrementar o intercâmbio de bens ou serviços do produtor até o consumidor final. ${ }^{34}$ São duas linhas principais de atuação: (i) gerar no interessado o reconhecimento da potencialidade de valor no intercâmbio e (ii) manter tal reconhecimento, mediante monitoramento e ações que gerem a satisfação dos interessados/clientes. ${ }^{35}$

90. Ações de assessoria de marketing no Brasil são normalmente ofertadas por agências de publicidade. Os contratos entre agências e demandantes normalmente envolvem um orçamento a ser administrado pela agência no interesse do cliente. É segundo o orçamento investido que o Instituto Kantar IbopeMedia organiza anualmente um ranking das maiores agências brasileiras. Destaco abaixo as dez maiores agências do mercado brasileiro em 2015 segundo este critério: ${ }^{36}$

$\begin{array}{ccc}\text { Posição } & \text { Agência } & \begin{array}{c}\text { Investimento } \\ (\mathrm{R} \$ \mathrm{mil})\end{array} \\ 1 & \text { Y R } & 7.022 .245 \\ 2 & \text { OGILVY E MATHER BRASIL } & 3.820 .652 \\ 3 & \text { AFRICA } & 3.507 .865 \\ 4 & \text { WMCCANN } & 3.502 .086 \\ 5 & \text { ALMAP BBDO } & 3.444 .893 \\ 6 & 3.231 .056 \\ 7 & \text { LEO BURNETT TAILOR MADE } & 2.825 .379 \\ 8 & \text { HAVAS WORLDWIDE } & 2.695 .074 \\ 9 & \text { MULLEN LOWE BRASIL * } & 2.591 .769 \\ 10 & \text { PUBLICIS PBC COMUNICACAO } & 2.461 .408\end{array}$

91. Nenhuma das maiores agências pertence às requerentes ou a grupos de radiodifusão, o que induz a um juízo preliminar de inexistência de concentração significativa neste campo. Problemas concorrenciais decorrentes da

34 COBRA, Marcos, BREZZO, Roberto. O Novo Marketing. Rio de Janeiro: Elsevier, 2010, p. 5-10.

35 MOORE, Karl; PAREEK, Nineth. Marketing: the basics. Nova Iorque: Routledge, 2006, p. 9.

36 https://www.kantaribopemedia.com/ranking-de-agencias-janeiro-\%D0\%B0-dezembro-2015/, consulta em 21 de abril de 2016. 
aliança entre as requerentes para assessoria de marketing não estariam no campo da oferta de serviços a clientes finais, mas na possibilidade de coordenação na oferta de tempo de televisão usado para anúncios em publicidade.

92. Radiodifusoras normalmente são fornecedoras de agências e não concorrentes. Elas servem como janela preferencial para campanhas. Dentre os gastos no Brasil em campanhas publicitárias por tipo de mídia, a que tem maior volume investido é a televisão aberta: ${ }^{37}$

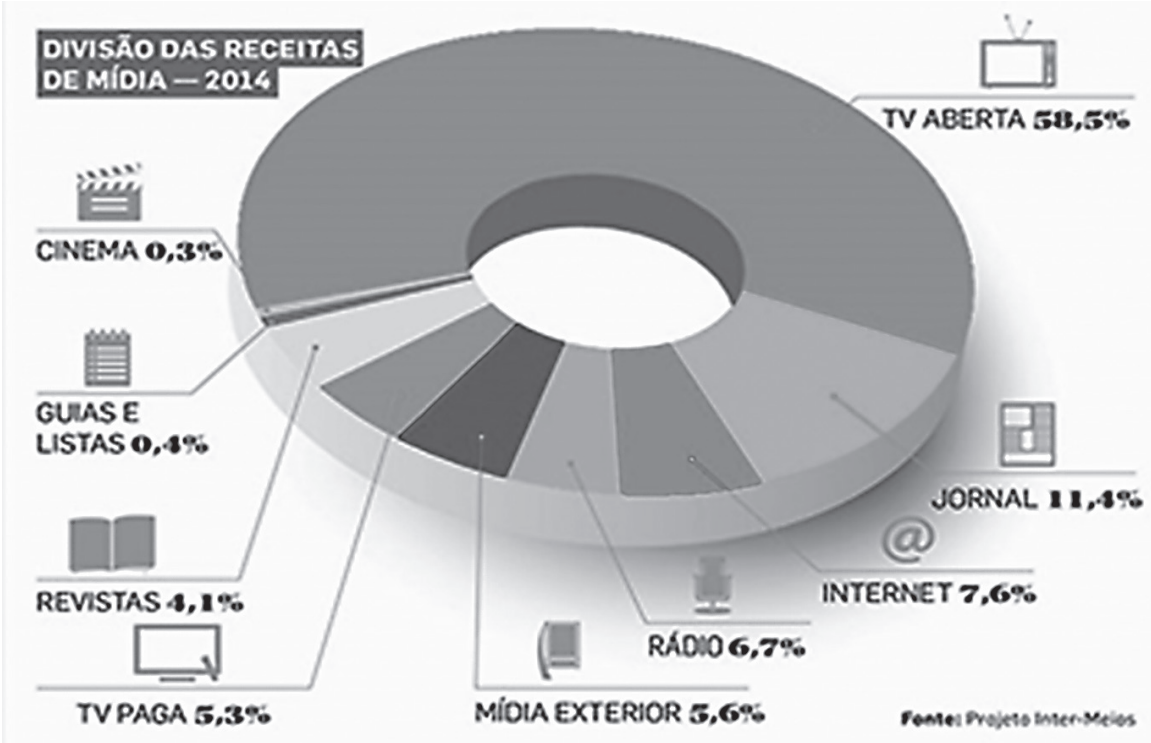

93. Como já visto, o mercado de televisão se caracteriza como um mercado de dois lados, onde há transações econômicas em duas frentes: em uma delas as fornecedoras da programação prestam serviços aos telespectadores e na outra frente oferecem espaços publicitários com potencial de audiência para as empresas ou entidades interessadas. Na televisão por assinatura há cobrança pelo acesso à programação, enquanto que na radiodifusão pura a publicidade subsidia o acesso ao conteúdo final pelos telespectadores.

94. Haveria riscos, dependendo do poder de mercado conjunto das requerentes, se a joint venture servisse para, de qualquer forma, coordenar

37 Fonte: Projeto Intermeios 2014. http://www.meioemensagem.com.br/home/midia/2015/04/27/mer cado-cresce-1-5-porcento-em-2014.html. Consulta em 21 de abril de 2016. 
ou gerar efeito de coordenação na venda de espaço publicitário para a programação dos canais de TV aberta que paralelamente mantêm (e que deve ser idêntica à contida no sinal fornecido para as operadoras de TV por assinatura).

95. O risco haveria neste campo mesmo se a joint venture restringisse seus serviços a uma consultoria comercial às suas sócias e não a terceiros. Neste modelo a JV teria acesso a dados sensíveis das empresas. Tendo acesso a dados das três concorrentes no fornecimento de programação de televisão aberta, um consultor hipotético certamente usaria de toda a informação disponível para gerar o melhor resultado possível com suas decisões.

96. Em tal situação, para maximizar os ganhos, o consultor tomaria decisões individuais para seus clientes de forma coordenada, como se estes formassem uma empresa única, usando do poder de mercado conjunto das emissoras para pressionar as negociações, aumentando artificialmente os preços e elevando o lucro de seus clientes.

97. Observo, contudo, que uma análise minuciosa de possibilidade e probabilidade de exercício de poder de mercado neste sentido não se fez necessária. Nos entendimentos preliminares sobre remédios aplicáveis ao presente ato de concentração, destaquei tal questão para as requerentes. Elas, reconhecendo os riscos, alteraram o objeto social e fizeram constar expressamente no contrato social apresentado que a assessoria de marketing a ser prestada não envolverá troca de informações, colocação, mediação, compra, venda, veiculação ou divulgação de material e espaço publicitário em programação de televisão aberta.

\subsubsection{Licenciamento de sinal de canais de TV aberta para operadores de televisão por assinatura no Brasil - definição de mercado relevante}

98. Dentre os mercados afetados por esta operação, nenhum merece maior consideração do que o de venda e distribuição dos canais abertos de televisão para operadores de televisão por assinatura.

99. No início do processo as requerentes sustentaram que:

[...] atuam no mercado de TV aberta, ofertando ao público conteúdo produzido internamente (novelas, telejornais, programas de auditório, etc.) e conteúdo adquirido de terceiros (seriados, filmes, eventos esportivos, etc.). Elas são 
remuneradas pela receita gerada pela venda de espaço para inserção de publicidade ao longo da programação.

V.2. A Newco será uma empresa independente, que atuará no licenciamento dos canais de programação das Requerentes para as Operadoras [de TV por assinatura]. Ou seja, a Newco atuará em mercado distinto daquele em que as Requerentes atuam - e competem acirradamente - hoje. [Requerimento Inicial]

100. A tese das requerentes se pautava na dualidade de acesso aos sinais dos canais de programação televisiva que ora ofertam. Uma parte dos telespectadores acessa diretamente tais sinais via recepção das emissões radioelétricas feitas a partir de antenas das próprias requerentes ou a partir de antenas de suas afiliadas, retransmissoras ou repetidoras (rede de radiodifusores que adquirem e repetem a maior parte de suas programações). Outra parte acessa via retransmissão de sinal feita por operadores de SeAC, que adquirem estes canais das próprias requerentes.

101. Sucede que o licenciamento de tais canais para as operadoras de SeAC até os dias atuais aconteceu, ainda que de forma gratuita (a preço zero). A gratuidade se deu por inércia de prática decorrente do modelo regulatório aplicado ao sinal analógico de televisão que impunha oferta compulsória e a título gratuito $^{38}$ (regime must offer-must carry).

102. A Lei $\mathrm{n}^{\mathbf{0}}$ 12.485/2011 inseriu possibilidade de nova fonte de remuneração para as radiodifusoras que forneçam sinal digital a operadoras de SeAC. O regime é idêntico à prática estrangeira chamada de retransmission consent. Dispôs que:

38 Lei no 8.977/1995 (dispõe sobre o serviço de TV a cabo): “Art. 23. A operadora de TV a Cabo, na sua área de prestação do serviço, deverá tornar disponíveis canais para as seguintes destinações:

I - CANAIS BÁSICOS DE UTILIZAÇÃO GRATUITA:

a) canais destinados à distribuição obrigatória, integral e simultânea, sem inserção de qualquer informação, da programação das emissoras geradoras locais de radiodifusão de sons e imagens, em VHF ou UHF, abertos e não codificados, cujo sinal alcance a área do serviço de TV a Cabo e apresente nível técnico adequado, conforme padrões estabelecidos pelo Poder Executivo;" Também Lei no 12.485/2011(lei do SeAC):" Art. 32. A prestadora do serviço de acesso condicionado, em sua área de prestação, independentemente de tecnologia de distribuição empregada, deverá tornar disponíveis, sem quaisquer ônus ou custos adicionais para seus assinantes, em todos os pacotes ofertados, canais de programação de distribuição obrigatória para as seguintes destinações: I - canais destinados à distribuição integral e simultânea, sem inserção de qualquer informação, do sinal aberto e não codificado, transmitido em tecnologia analógica pelas geradoras locais de radiodifusão de sons e imagens, em qualquer faixa de frequências, nos limites territoriais da área de cobertura da concessão;" 
Art. 32 [...] \$12. A geradora local de radiodifusão de sons e imagens de caráter privado poderá, a seu critério, ofertar sua programação transmitida com tecnologia digital para as distribuidoras de forma isonômica e não discriminatória, nas condições comerciais pactuadas entre as partes e nos termos técnicos estabelecidos pela Anatel, ficando, na hipótese de pactuação, facultada à prestadora do serviço de acesso condicionado a descontinuidade da transmissão da programação com tecnologia analógica prevista no inciso I deste artigo.

103. Muito embora a Lei oํ 12.485/2011 tenha sido publicada em 12 de setembro de 2011, as geradoras de radiodifusão de sons e imagens não instituíram imediatamente sistema de cobrança pelo sinal digital ofertado às operadoras de SeAC. Tal panorama se alterou apenas mais recentemente, possivelmente a partir de 2014, quando a TV Globo logrou negociar contratos com previsão de remuneração pelo provimento do sinal de TV aberta gerado por esta empresa. Este padrão de remuneração foi transportado para as negociações envolvendo suas afiliadas e repetidoras.

104. Seja como for, noto que o fornecimento de sinal para operadoras de SeAC não é uma atividade inédita para as requerentes e por isso deve ser descartada a tese de que não há sobreposição horizontal.

105. Segundo o vigente Guia SEAE-SDE para Análise Econômica de Atos de Concentração Horizontal: ${ }^{39}$

A definição de um mercado relevante é o processo de identificação do conjunto de agentes econômicos, consumidores e produtores, que efetivamente limitam as decisões referentes a preços e quantidades da empresa resultante da operação. Dentro dos limites de um mercado, a reação dos consumidores e produtores a mudanças nos preços relativos - o grau de substituição entre os produtos ou fontes de produtores - é maior do que fora destes limites.

106. Qual seria o conjunto de consumidores e produtores que efetivamente limitariam as decisões referentes a preços e quantidades da empresa resultante da operação analisada? Se a joint venture, que pretende controlar a

39 Está em elaboração novo Guia de Análise de Concentração Horizontal, que ficou em Consulta Pública de 17.03.2016 a 30.04.2016 (http://www.cade.gov.br/upload/Guia\%20de\%20AC\%20horizon tal.pdf). O texto de proposto para a introdução à ideia da definição de mercado relevante é, por hora, muito semelhante: "A definição do MR é o processo de identificação do conjunto de agentes econômicos (consumidores e produtores) que efetivamente reagem e limitam as decisões referentes a preços e quantidades da empresa resultante da operação". 
negociação dos sinais digitais de três canais de televisão aberta (SBT, Record e Rede TV!), resolver negar acesso dos demandantes aos bens que não aceitarem suas condições, como os demandantes podem pressionar para limitar tais condições?

107. A forma mais aceita de pressão no mercado é a fuga de demanda. Se um tal fornecedor não satisfaz os anseios dos demandantes, este tende a migrar para um segundo ou terceiro que ofereça melhores condições. Tendo conhecimento de tal ameaça, os ofertantes tendem a limitar preços e exigências, de modo a não perder vendas.

108. Mesmo argumentando que não haveria sobreposição horizontal, as requerentes retratam da seguinte forma o universo do mercado relevante:

[...] o mercado de licenciamento de canais para TV por assinatura não deve ser segmentado com base no conteúdo ou nacionalidade da programação de cada canal, pelas seguintes razões.

Em primeiro lugar, as empresas que se dedicam a programação de canais para os serviços de televisão por assinatura, tais como Fox, Discovery, Viacom, Disney, Turner e Globosat, buscam compor um grupo de canais com perfis variados de público e interesse para ganhar força de negociação frente às operadoras. Comumente essas empresas condicionam a disponibilização de um determinado canal mais popular (e por isso gera maior interesse de assinantes) à inclusão de um ou mais canais do grupo em tipos específicos de pacote.

Além disso, os assinantes de TV paga compram um conjunto variado de conteúdo audiovisual, comercializado pelas Operadoras. Nesse cenário, todos os canais competem pela audiência dos assinantes.

[...]

Os clientes das operadoras [...] têm assim possibilidade de escolher assistir um noticiário na Record ou na Globonews, a um desenho animado na Discovery Kids ou no SBT, a um programa de auditório no Multishow ou na Rede TV, a um jogo de futebol na Globo ou na ESPN, a uma minissérie da Globo ou uma série da Warner ou do Universal, etc. [Item V.5 do Anexo II da Notificação da Operação]

109. No mesmo sentido do voto da Conselheira Relatora, entendo que tal visão não procede, embora com razões ligeiramente diferentes.

110. Em primeiro lugar, acho que as considerações sobre escolhas do consumidor final sobre o que assistir não são as mais adequadas para definir 
mercado relevante, porque elas, as escolhas, se dão em momento posterior às transações afetadas pelo objeto da joint venture. As transações afetadas serão as escolhas feitas pelas operadoras para compor pacotes de canais ofertados aos assinantes. Uma vez que a operadora já tenha logrado convencer um assinante a aderir a um ou mais pacotes, trocar de canal não tem qualquer custo e não representa migração direta de demanda.

111. As programadoras de canais de televisão ofertam programação linear para operadoras de televisão por assinatura e é a tensão existente nesta relação que deve ser o centro da definição do mercado relevante. Deve-se perguntar: uma vez que uma dada programadora aumente o preço de um canal ou do conjunto de canais, é possível à operadora facilmente substituir tal canal nos grupos transmitidos aos seus assinantes? No caso em tela: se um ofertante hipotético impuser a aquisição conjunta dos canais SBT, Record e SBT, é crível que as operadoras de SeAC substituirão tais canais nos pacotes em que eles normalmente são inseridos por outros como Globo News, Discovery Kids, Multishow, ESPN, Warner ou Universal? Me parece que a resposta deva ser negativa, dada a diferenciação das características entre estes canais. Em algum grau podem ser substitutos, mas não no nível de substitutos próximos que exige a defesa da concorrência.

112. Ainda que se considere que são partes interessadas nesta operação, vejo que no mesmo sentido foi a resposta dos agentes de mercado e considero válidos os argumentos apresentados:

Em razão da alta relevância dos canais SBT, Record e Rede TV na programação da Operadora de TV por assinatura (em particular as 2 primeiras), a mesma não lograria êxito em desviar a demanda para outros canais de sua grade de programação. Até porque, as Requerentes possuem em seus conteúdos produzidos, características próprias - condizentes, principalmente, com a cultura brasileira - que não permitem sua substituição por outro canal.

[...] Além disso, os canais de TV aberta em geral, cuja análise ora se volta para as Requerentes, possuem características próprias que não permitem a sua substituição por outros canais. Trata-se de conteúdo de relevância sociocultural e com uma abrangência e audiência tão relevante que o usuário médio considera essencial como fonte de informação e para o seu entretenimento. De fato, o fato de ter um conteúdo de interesse local, em língua portuguesa e direcionada para o público brasileiro associada a uma audiência muito abrangente gera um efeito de rede relevante. De fato, o conteúdo dessas Requerentes torna-se importante no contexto do convívio social dos assinantes de televisão por assinatura. 
Torna-se, assim, inviável (ou muito pouco competitivo) a oferta de conjunto de canais sem determinados conteúdos, incluindo o da SBT, Record e RedeTV (e, em particular, como já referido, o conteúdo das 2 primeiras). [Resposta da Telefônica-Vivo ao Ofício CADE no 4312/2015, SEI 0099219]

[...] a programação transmitida pelas Requerentes não encontra semelhança com qualquer programação transmitida ou por outro canal de "TV paga", considerando-se principalmente suas características, tais como conteúdo local em Português, regionalização, novelas, jornalismo, etc., que diferem em muito do conteúdo dos demais canais de televisão por assinatura. A programação transmitida pelas Requerentes é, portanto, relevante para os consumidores do serviço de acesso condicionado e não encontra, atualmente, substitutos. [Resposta da Claro S.A.-NET ao Ofício CADE nº 4314/2015, SEI 0098089]

113. Neste sentido, considero que, para definição do mercado relevante, é apenas indireta a importância das preferências do consumidor final enquanto está assistindo à televisão por assinatura. As trocas feitas por meio do controle remoto não devem ser elemento principal para definir mercado relevante neste ato de concentração. Isto porque ao ajustar o seletor de canais o consumidor final escolhe apenas entre aqueles cujo preço de acesso já foi pago e integram o pacote contratado junto à operadora.

114. A comercialização de canais avulsos, mesmo com a intermediação da operadora, não é uma forma usual de oferta, menos ainda para este tipo de canal (programação de TV aberta). O cardápio no qual a escolha marginalmente onerosa do consumidor final se dá é um menu de pacotes de canais já agregados e é entre estes cardápios completos, chamados de planos de assinatura, que incidem as escolhas onerosas sobre produto final da televisão paga. Para evitar que portfólios de um grupo de pacotes se posicionem de modo conflitante perante o mesmo tipo de clientela ("canibalização") as operadoras de SeAC agrupam famílias de canais afins de modo a lograr discriminação de preços. Os conteúdos são classificados de mais básicos até mais exclusivos ("premium") e a variação de preços segue esta gradação.

115. Assim, a principal escolha que pode ser limitada por este ato de concentração é aquela feita pelas operadoras para compor os pacotes oferecidos no mercado. Nesta composição faz sentido segmentar canais por gêneros, porque é assim que eles são mercadologicamente oferecidos pelas operadoras, visando atingir a composição que tem maior penetração para diversas categorias de público. O gênero no qual são correntemente classificados os 
canais das requerentes é TV aberta. Veja-se, por exemplo, as ofertas feitas pelas principais operadoras na atualidade:

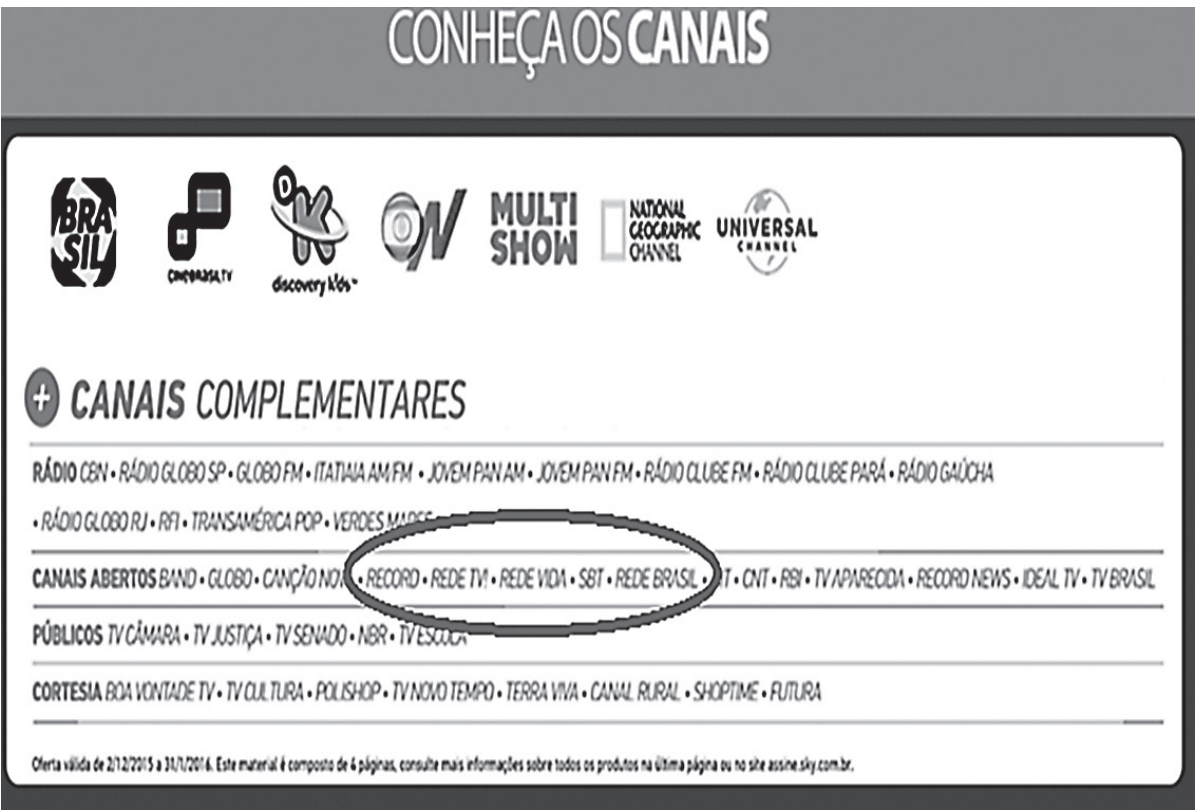

Descrição de grupo de canais oferecidos pela Sky em plano básico (http://www.planoprepagosky. com.br/?utm_cms=CENTRALDEASSINATURAS, consulta em 24 de abril de 2016). 
30 - NET TV

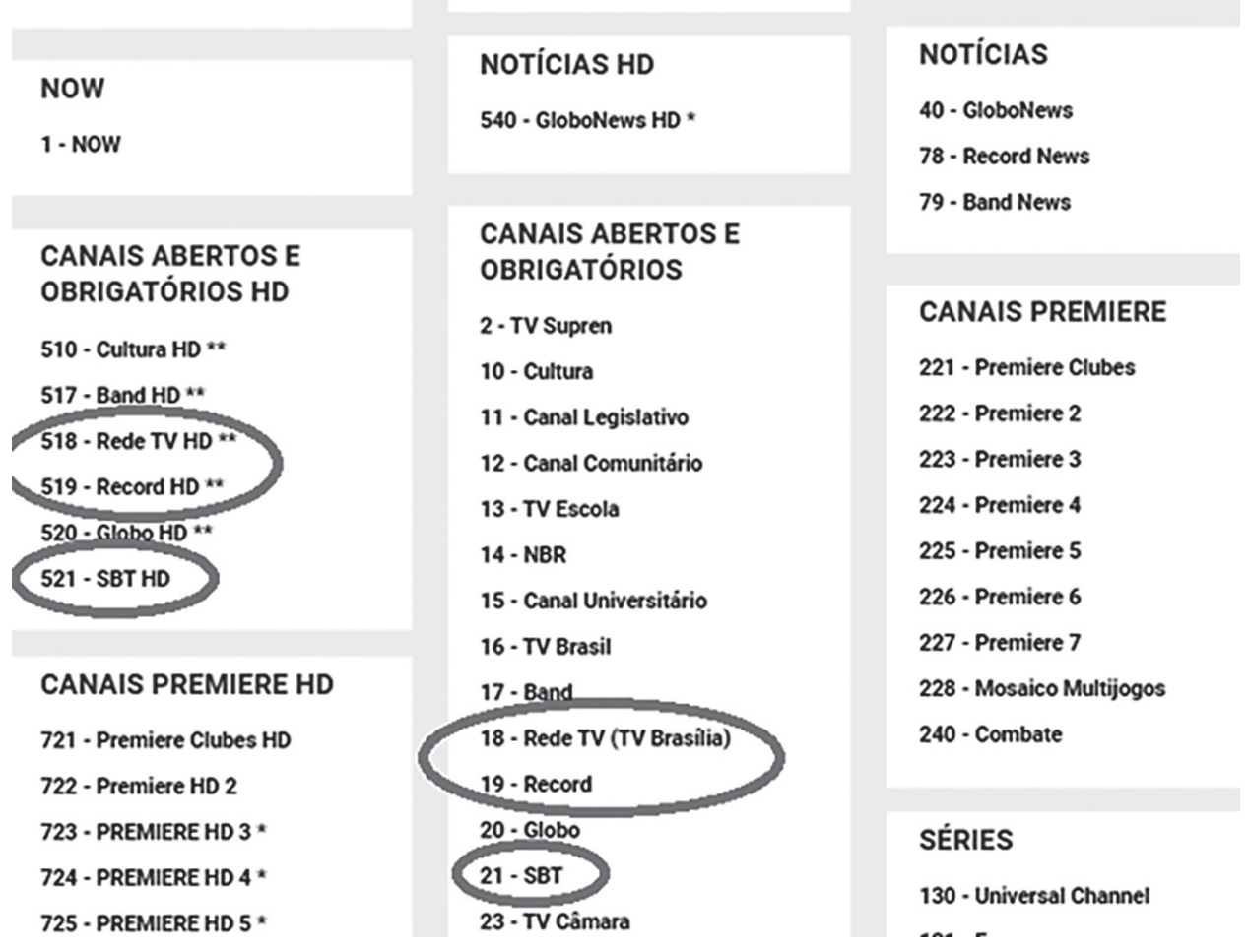

Descrição de grupo de canais oferecidos pela Net em plano básico (http://www.netcombo.com. br/TV-por-assinatura/programacao/guia-de-canais, consulta em 24 de abril de 2016). 


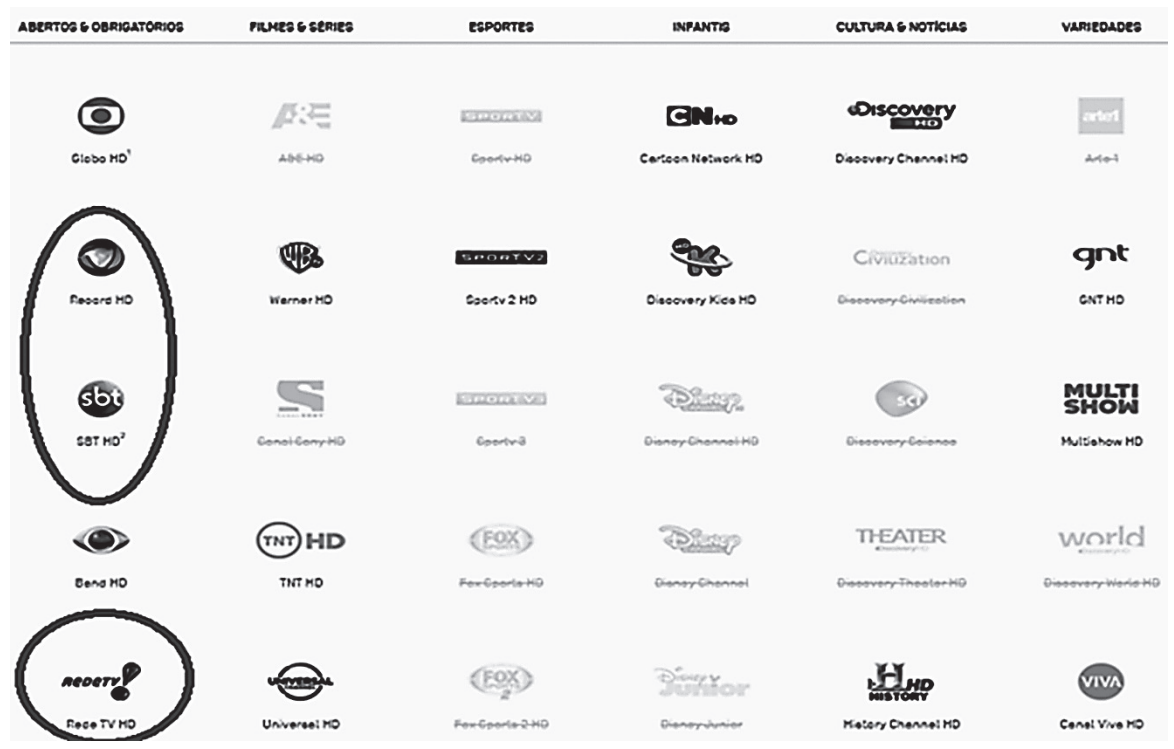

Descrição de grupo de canais oferecidos pela Oi em plano básico (http://www.oi.com.br/TVhd/\#!start-hd-cliente-atual, consulta em 24 de abril de 2016).

Canais de Noticias

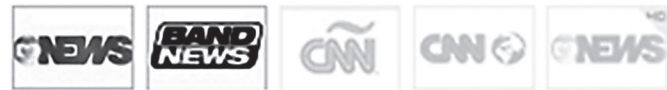

Canais Abertos
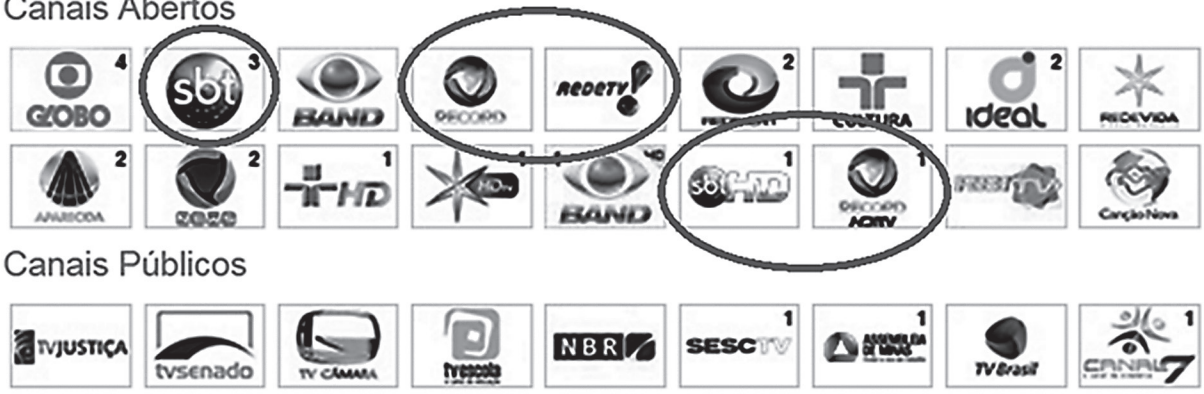

Descrição de grupo de canais oferecidos pela Algar Telecom em plano básico (http://www. algartelecom.com.br/section.do?CodSec=18454, consulta em 24 de abril de 2016). 
116. Nem as requerentes ofertam e nem a joint venture pretende ofertar diretamente ao consumidor final, por meio de SeAC, o sinal de sua(s) programação(ões). ${ }^{40} \mathrm{O}$ licenciamento de sinal de canal de TV aberta é um insumo que tem como demandante a operadora de TV paga. A operadora adquire este insumo e compõe pacotes. É o mercado de alocação deste bem intermediário, que pode ser descrito como licenciamento de canais de televisão aberta para retransmissão em $S e A C$, a dimensão produto do mercado diretamente afetado pelo ato de concentração. Se a operadora não tiver acesso a SBT, Record ou Rede TV! procurará migrar sua demanda para um canal de mesmo gênero (televisão aberta) e não para gênero completamente distinto. É certo que a audiência média de qualquer canal junto ao consumidor final é um elemento muito importante para a operadora de SeAC escolher o que deve compor seus pacotes, mas isto deve ser considerado nas medidas que se faça sobre incremento de poder no mercado relevante e não na definição do mercado relevante em si mesma.

117. Por fim, registro que dimensão produto de mercado relevante baseada em gêneros de programação tem respaldo na jurisprudência do CADE. No Ato de Concentração nº 08012.002417/2010-60 (Sony Pictures Entertainment Inc. e HBO Latin America) o Conselheiro Carlos Ragazzo pontuou que:

40. Em processos anteriores sobre o mesmo mercado, vários clientes e concorrentes consultados apontaram como principais substitutos dos canais distribuídos pelas requerentes daqueles processos canais do mesmo gênero. Neste sentido, torna-se mister salientar que canais de gêneros diversos não substituem canais com programação específica.

41. Em outras palavras, um canal de filmes premium (caso do $\mathrm{HBO}$, por exemplo, que exibe filmes mais recentes) não substituiria um canal infantil, ou um canal de variedades, ou mesmo um canal de filmes dublados, mais antigos (exibidos em segunda ou terceira janela, ou seja, que já foram transmitidos por canais de filmes premium). Mesmo a substituibilidade entre canais de variedades não se apresenta de forma trivial, pois cada canal é formatado para determinado público-alvo.

42. [...] Desta forma, o mercado de distribuição de canais para TV por assinatura tende a ser segmentado por gênero, havendo necessidade de se avaliar caso a caso a mais correta definição de mercado relevante sob a dimensão produto. 40 Para o médio prazo planeja-se adaptação a mudanças do mercado provocada por serviços de
streaming, video on demand. 


\begin{tabular}{|c|c|c|}
\hline \multicolumn{3}{|c|}{$\begin{array}{c}\text { Quadro II } \\
\text { Categorização dos Canais }\end{array}$} \\
\hline Segmento de Programação & Grupo Time Warner & Grupo HBO \\
\hline Filmes e Séries & TNT, TCM, Infinito, Space & Animax, Warner Channel \\
\hline Filmes & & $\begin{array}{l}\text { Cinemax, Cinemax*, HBO, } \\
\text { HBO2, HBO Family, HBO } \\
\text { Family*e, HBO Plus, HBO } \\
\text { Plus*e, Max Prime, Max } \\
\text { Prime*e }\end{array}$ \\
\hline Infantil & TCN, Boom, & \\
\hline Jornalistico & CNNI, CNNE & \\
\hline Variedades & FTV & E! \\
\hline Filmes, Séries e Documentários & I.SAT, & \\
\hline Filmes, Séries e Shows & & A\&E, AXN \\
\hline Música & Much Music & \\
\hline Biografias & & Biograph \\
\hline $\begin{array}{c}\text { Filmes, Reality Shows e Produções } \\
\text { Originais }\end{array}$ & & Sony \\
\hline Filmes, Séries e Reality Shows & & $\mathrm{AXN}$ \\
\hline Documentários & & The History Channel \\
\hline
\end{tabular}

Fonte: Globosat.

118. No mesmo sentido, segmentando mercados relevantes segundo o gênero do canal para TV por assinatura, cito o PA no 08012.003048/2001-31 (práticas restritivas de Globo e Globosat no mercado de programação esportiva nacional para TV por assinatura, Rel. Cons. Paulo Furquim de Azevedo) e o AC n⿳0 08012.004909/2001-07 (The News Corporation e Walt Disney Company, Rel. Cons. Afonso Arinos de Mello Franco Neto). ${ }^{41}$

119. Quanto à dimensão geográfica, noto que, por disposição constitucional, emissoras de televisão aberta devem ser necessariamente empresas nacionais com sede no Brasil - mais, devem pertencer a brasileiros natos ou naturalizados há mais de dez anos. ${ }^{42}$ Para além das condicionantes da radiodifusão, qualquer atividade de programação para SeAC deve necessariamente ser desenvolvida por empresas brasileiras e sediadas no Brasil,

41 Referências de mesma metodologia na Comissão Europeia: News Corp/BSkyB (M.5932), HBO/ Ziggo/HBO Nederland (M.6369), Bertelsmann/KKR/JV (M.5533), Sony/MGM (M.3595), Lagardere/ Sportfive (M.4519) e Time Warner/CME (M.6866). Sem se preocupar em segmentar por gênero, em função de entender sumariamente baixa preocupação concorrencial e participação de mercado os ACs n⿳o 08012.010373/2009-16 (GE, Comcast e NBC Universal, Rel. Cons. Ricardo Ruiz), 08012.000157/2007-92 (Time Warner e Claxson, Rel. Luis Fernando Schuartz).

42 "Art. 222. A propriedade de empresa jornalística e de radiodifusão sonora e de sons e imagens é privativa de brasileiros natos ou naturalizados há mais de dez anos, ou de pessoas jurídicas constituídas sob as leis brasileiras e que tenham sede no País." (Redação dada pela Emenda Constitucional nº 36, de 2002). 
conforme art. 9º da Lei $\mathrm{n}^{\mathrm{o}}$ 12.485: "As atividades de produção, programação e empacotamento são livres para empresas constituídas sob as leis brasileiras e com sede e administração no País". Tais restrições regulatórias limitam a dimensão geográfica do mercado relevante ao território nacional. ${ }^{43}$

120. Definido o mercado relevante, a magnitude do impacto da união dos agentes envolvidos é tema a ser apresentado adiante. Visto, a partir da definição do mercado relevante, que um núcleo importante do ato de concentração notificado gira em torno da criação de condições, mediante colaboração entre competidores, para elevação de poder de barganha, teço algumas considerações sobre o modo de apreciação de contratos desta natureza a seguir.

\section{III.3. Sobre a avaliação antitruste de joint ventures}

121. A coordenação entre competidores é um tema delicado em defesa da concorrência. $\mathrm{O}$ risco de acordos que impliquem redução de oferta é uma constante. Inobstante, é um tema que sempre deve ser enfrentado, pois naturalmente povoa a realidade econômica e pode resultar em incremento de bem-estar social. Com efeito, competidores estão entre os agentes que melhor conhecem o mercado e suas demandas e é possível que o encontro de know-how permita com que façam juntos algo que não é possível em esforços isolados. Neste caso o encontro acontece em benefício do maior e/ou melhor atendimento às necessidades dos consumidores. ${ }^{44}$

122. As joint ventures são tipo especial de arranjo cujas características normalmente são vistas como neutras ou benéficas ao ambiente competitivo. Uma boa tradução do termo joint venture aponta para o significado empreendimento com riscos ou responsabilidades divididas.

123. Para fins concorrenciais, joint ventures clássicas são aquelas cuja missão é servir como veículo exploratório das empresas criadoras em mercados desconhecidos, seja este desconhecimento de um mercado geográfico ou

43 Limitando ao mercado nacional o licenciamento de canais para TV por assinatura: PA nº 08012.003048/2001-31 (práticas restritivas de Globo e Globosat no mercado de programação esportiva nacional para TV por assinatura, Rel. Cons. Paulo Furquim de Azevedo) e ACs $\mathrm{n}^{\circ}$ 08012.004909/2001-07 (The News Corporation e Walt Disney Company, Rel. Cons. Afonso Arinos de Mello Franco Neto), 08012.010373/2009-16 (GE, Comcast e NBC Universal, Rel. Cons. Ricardo Ruiz), 08012.000157/2007-92 (Time Warner e Claxson, Rel. Luis Fernando Schuartz).

44 HARRIGAN, Kathryn Rudie. Joint Ventures, Alliances and Corporate Strategies. Washington, DC: Beard Books, 2003. 
temático. Nestes casos, as formações mais comuns de joint ventures relacionamse a indústrias de inovação, de serviços, de produtos diferenciados, intensivas em capital ou ainda à entrada em mercados estrangeiros. Como na modalidade clássica este tipo de sociedade é sempre meio de entrada em mercados não relacionados horizontalmente ou verticalmente, a Resolução CADE no 2/2012 prevê que a avaliação de impactos concorrenciais aconteça em procedimento simplificado e sumariamente tendente à aprovação sem restrições (art. 8o , I). ${ }^{45}$

124.Sociedadesqueseafastem destemodelo, porém, podemexigiravaliação antitruste detalhada. Os riscos concorrenciais mais comuns associados a joint ventures não clássicas são aqueles atinentes a limitações a decisões comerciais independentes, controle compartilhado de ativos produtivos importantes, facilitação a trocas de informações concorrencialmente sensíveis, incentivos a redução de competição em outros mercados que não o do empreendimento conjunto e outros elementos que indiquem aumento de risco de colusão tácita ou explícita. ${ }^{46}$

125. A atividade de licenciamento conjunto de sinais de TVs abertas das sócias da empresa ora analisada implica sobreposição horizontal em relação às atividades das requerentes. Mais que isso, possibilita prática de venda casada e objetiva elevação da capacidade de impor um preço a este conjunto de sinais (hoje a oferta é gratuita). São razões suficientes para que não seja considerada uma joint venture clássica para fins concorrenciais. Logo, não se sujeita a análise sumária.

126. A questão, porém, não é apenas definir se cabível análise superficial ou aprofundada do ato de concentração. Para tais casos cabe questionamento acerca do critério a ser aplicado na avaliação concorrencial completa. Isto porque há forte rejeição a arranjos deste tipo que sejam formados à margem do conhecimento da autoridade da concorrência. ${ }^{47}$ Normalmente são tratados como cartel e presumidos efeitos líquidos negativos.

127. Assim, se uma sociedade tem por objeto aumentar poder de barganha - algo aproximado ao que se faz em um cartel - , ela deve ser avaliada

45 “Art. 8 São hipóteses enquadráveis no Procedimento Sumário, as seguintes operações:

I - Joint-Ventures clássicas ou cooperativas: casos de associação de duas ou mais empresas separadas para a formação de nova empresa, sob controle comum, que visa única e exclusivamente à participação em um mercado cujos produtos/serviços não estejam horizontal ou verticalmente relacionados;"

46 ABA - American Bar Association, Section of Antitrust Law. Joint Ventures: Antitrust Analysis of Colaborations Among Competitors. Chicago: ABA Publishing, 2006, p. 2.

47 Aqui à margem do conhecimento da autoridade significa sem notificação. Não se entende, contudo, que a furtividade seja um elemento jurídico essencial da caracterização do cartel, embora possa ser empiricamente apontada como uma característica frequente. 
segundo o corrente critério aplicado a atos de concentração, de configuração de efeito líquido não negativo, ou, neste caso particular, se deve exigir necessariamente efeito líquido positivo ${ }^{48}$ No primeiro caso bastam elementos estruturais no mercado que denotem que o exercício de poder de mercado é improvável ou não deve ter efeitos no consumidor final, no segundo caso os efeitos negativos são presumidos e apenas afastados se demonstrada que a operação propicia resultado líquido positivo. Busquei a resposta em práticas antitrustes adotadas por outras jurisdições.

128. Algumas autoridades antitruste no mundo expressam grande preocupação com joint ventures cujo único ou dominante objetivo seja elevar poder de mercado, gerando pouca integração produtiva. Por todas, cito trecho do sumário executivo da mesa-redonda da OCDE que abordou temas concorrenciais em Joint Ventures e contabilizou colaboração de 14 jurisdições: ${ }^{49}$

Joint ventures apresentam um largo espectro em termos avaliação de custo-benefício quando o tema são efeitos pró e anticompetitivos. Questões envolvendo sociedades que apresentem grandes vantagens ou desvantagens podem ser facilmente endereçadas.

Algumas joint ventures têm poucos ou nenhum efeito anticompetitivo, na medida em que oferecem eficiências concretas. Estão incluídas nesta categoria as sociedades que têm atividades cujas sócias-constituintes não têm capacidade de desenvolver isoladamente e que não envolvam cláusulas de restrição da competição preexistente entre elas. Bons exemplos deste tipo de joint venture são aquelas que permitem importantes economias de escala por meio da produção conjunta de insumos que representem pequena parcela do custo total da atividade comercial das empresas constituintes. Joint ventures deste tipo não devem apresentar dificuldade real para autoridades da concorrência. Devem ser permitidas tacitamente ou aprovadas o mais rápido possível.

No outro extremo do espectro há joint ventures que não oferecem qualquer benefício concreto, mas implicam em riscos substanciais à concorrência. Tipicamente, estes acordos envolvem pouca integração produtiva entre as empresas constituintes. Uma vez determinado que uma joint venture se encaixa em uma

48 Neste último caso tomando-se as restrições intrínsecas como ancilares a um outro objeto pró-competitivo.

49 Austrália, República Tcheca, Dinamarca, Alemanha, Itália, Japão, Coreia do Sul, Holanda, Turquia, Reino Unido, Departamento de Justiça dos Estados Unidos, Federal Trade Commmission dos Estados Unidos, Comissão Europeia e Brasil. 
destas categorias, ela deve ser sumariamente proibida, especialmente quando for uma clara fraude, i.e., um cartel hardcore disfarçado de joint venture. ${ }^{50}$

129. Nos Estados Unidos, tema absolutamente análogo ao descrito neste ato de concentração foi objeto de regulação da Federal Communications Commision - FCC - tomada a partir de provocação do Departamento de Justiça. ${ }^{51}$ Como descrito no voto da Conselheira Relatora (SEI 0172165):

Diante da Revisão Regulatória Quadrienal conduzida pela FCC (Federal Communications Commission) 62, o DoJ sustentou perante esse órgão regulador que a negociação conjunta do retransmission consent entre uma ou mais radiodifusoras deve ser considerada infração antitruste per se, diante da possibilidade de elevação de preço para o consumidor final. Para o DoJ, por isso, a análise pela regra da razão torna-se desnecessária neste caso. Ela só se justificaria quando a venda conjunta resultasse em aumento de eficiência e não no aumento do poder de barganha com o outro elo da cadeia produtiva. [...]

Pela experiência da FCC, com a autorização da negociação conjunta do retransmission consent, pode haver elevação do valor cobrado de $20 \%$ a $40 \%$ com relação aos preços praticados em livre competição (segundo o

50 Tradução livre, fonte: OCDE. Competition Issues in Joint Ventures. 2000, p. 9. Disponível em http:// www.oecd.org/competition/abuse/2379097.pdf, consulta em 02.05.2016. No original: "Joint ventures present a wide spectrum in terms of their cost-benefit ratios where costs refer to anti-competitive effects and benefits mean pro-competitive efficiencies. Joint ventures presenting either very low or very high cost-benefit ratios can easily be addressed.

Some joint ventures have few if any anti-competitive effects, while at the same time offering some real efficiency benefits. Included in this category are joint ventures conducting activities parents could not perform individually, and involving no restrictions on the competitive activities of the joint venturers. Good examples of such joint ventures are those set up to reap important economies of scale through common production of inputs accounting for a minor portion of the parents' total costs. Such joint ventures should present no real difficulty for competition authorities. They should simply be left alone or approved as quickly as possible.

At the other end of the spectrum are joint ventures offering no real benefits, but entailing substantial risks to competition. Typically such arrangements involve little in the way of real integration among the parents. Once it has been determined that a joint venture falls into this category, it can be summarily prohibited especially if it is essentially a sham, i.e. a "hard core" cartel masquerading as a joint venture." Também na linha de que arranjos de coordenação de variáveis sensíveis de mercado que não impliquem emintegração produtiva são mais gravosos do que fusões totais: "Um cartel formado por um grupo de produtores concorrentes é de muitas formas pior que uma fusão total entre estes produtores, porque uma fusão normalmente traz consigo algumas eficiências na forma de integração de processos produtivos" (NIELS, Gunnar; JENKINS, Helen; KAVANAGH, James. Economics for Competition Lawyers. Nova Iorque: Oxford University Press, 2011, p. 285). Tradução livre de "A cartel formed by a group of competing producers is in many ways worse than a full merger between those producers, because a merger normally brings with it some efficiencies in the form of integration of production processes".

51 FCC. In the Matter of Amendment of the Commission's Rules Related to Retransmission Consent. MB Docket no 10-71. Publicado em 31 de março de 2014. Disponível em: https://www.fcc.gov/document/ fcc-strengthens-retransmission-consent-rules-0, consulta em 02.05.2016. 
conselheiro Tom Wheeler). A FCC conclui que negociações conjuntas entre radiodifusoras que estejam entre as quatro maiores do ranking (segundo suas audiências) constituem uma violação à regra de negociação em "boa-fé" do retransmission consent, pois diminui a rivalidade entre as TVS abertas e pode, na negociação comercial com as operadoras, retirar canais desta nova empresa.

130. Observo que a proibição per se do FCC se aplica de modo restritivo apenas às quatro maiores emissoras segundo ranking nacional de audiência e não às demais. Para estas outras aplica-se a regra da razão, segundo as condições estruturais de mercado, independentemente de a joint venture poder ter como objeto a negociação do sinal digital de televisão aberta (retransmission consent). Isto indica que a análise de condições de mercado é cabível em casos justificados.

131. Observo ainda que a concentração de compradores de sinal para operadoras de TV é significativamente menor que no Brasil. Enquanto no Brasil as líderes Sky e Net têm aproximadamente 52\% e 28\% do número total de assinantes, nos EUA em 2015, apenas dois dos ofertantes de televisão por assinatura ultrapassavam a marca de $20 \% .^{52}$

52 O mercado atualmente busca consolidação, como se vê na aquisição da Time Warner Cable pela Charter, na fusão entre AT\&T e DirecTV e na tentativa de aquisição da Time Warner Cable pela Comcast (rejeitada pelos reguladores). 


\section{Provedores de Tv por Assinatura nos EUA em 2014 por número total de assinantes}

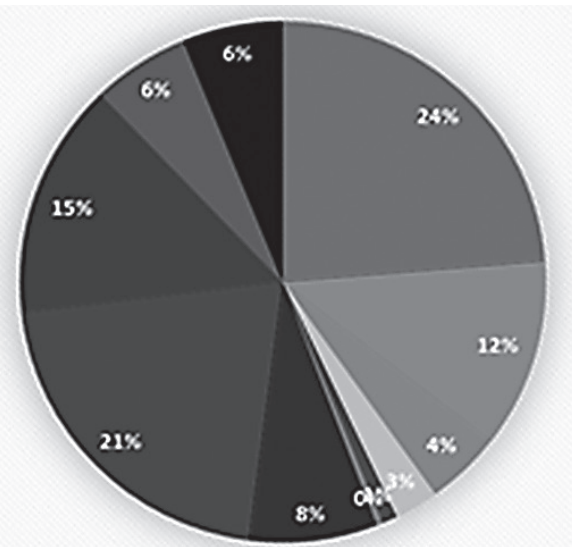

\begin{tabular}{|c|c|c|}
\hline a coencas: & a Time Wamer Cable & E Cabievision \\
\hline - Mrsizcom & a CaBle ONE & - ceher mujor private compuries" " DirectV \\
\hline$=\mathrm{OSHA}$ & DATET U.werse & - Verizon sios \\
\hline
\end{tabular}

Fonte: Elaboração própria a partir de dados de http://www.leichtmanresearch.com/press/031016 release.html, consulta em 02.05.2016.

\section{SeAC - número de assinantes}

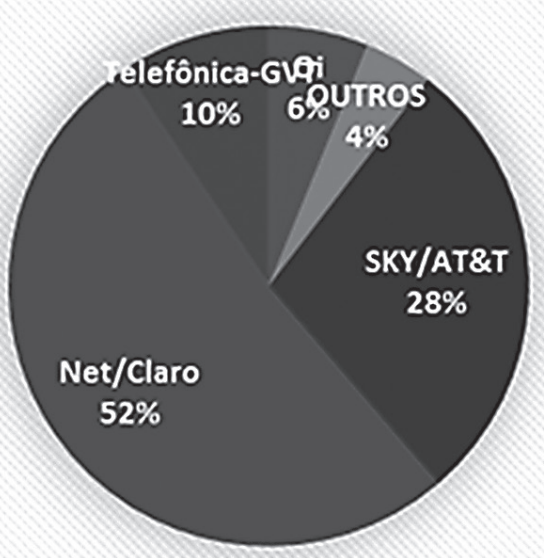

$\square \square \square \square \mathrm{Oi} \quad \square$ OUTROS $\square$ SKY/AT\&T $\square$ Net/Claro $\square$ Telefônica.GVT

Fonte: Elaboração própria a partir de dados de http://www.anatel.gov.br/dados/index.php/ component/content/article?id=215, consulta em 02.05.2016. 
132. Estas particularidades levam-me a crer cabível a análise da operação segundo a regra da razão no presente caso, bem como o dimensionamento de remédios segundo a avaliação a seguir empreendida.

133. A análise segundo a regra da razão de atos de concentração que podem implicar em restrição pura (naked restraint) à competição não é novidade neste CADE. A metodologia foi aplicada no Ato de Concentração no 08012.000052/2007-33 (joint venture de compra de minério de ferro formada entre Nippon Steel Corporation e Pohang Iron \& Steel Co. Ltd., julgado em 11.04.2006) e resultou no conforto para aprovação sem restrições - desfecho que adianto como incabível para o caso da Newco. Assim se posicionou o Conselheiro Relator Paulo Furquim de Azevedo naquele caso:

A operação em apreço merece uma análise cuidadosa deste órgão de defesa da concorrência por sua natureza de restrição pura. Trata-se de acordo de cooperação entre concorrentes, cujo escopo é a negociação conjunta de preço de um insumo. Seria um exemplo das chamadas naked restraints, que são acordos cujo objeto principal é a imposição de restrição sobre o preço, quantidades vendidas ou compradas, qualidade das mercadorias, ou qualquer outro fator que afete negativamente a concorrência. Assim, a operação em tela, se realizada em um mercado competitivo e entre agentes com poder de mercado, poderia causar danos graves à ordem econômica, tendo em vista que aumentaria o poder de monopsônio dos acordantes, que poderiam forçar uma depreciação do preço do insumo aquém do que seria socialmente desejável, gerando alocação ineficiente e perda de bem-estar econômico.

Contudo, o presente caso apresenta particularidades que afastam a possibilidade de dano à ordem econômica. Em primeiro lugar, o mercado internacional de compra e venda de minério de ferro não pode ser definido como competitivo, em que os preços são determinados pela relação entre funções de oferta e demanda, que expressam o comportamento de agentes pulverizados. Com efeito, trata-se de um mercado concentrado em dois níveis (compra evenda), em que os preços são determinados por meio de um processo de barganha bilateral, levando-se em conta não só a relação entre oferta e demanda, mas também o poder de barganha de cada agente envolvido. Em segundo lugar, e complementarmente à afirmação anterior, as requerentes, em conjunto, não possuiriam poder de monopsônio suficiente para suplantar o poder de monopólio detido pelos principais fornecedores mundiais de minério de ferro, o que também afasta a possibilidade de prejuízos à ordem econômica. 


\section{III.4. Possibilidade de exercício de poder de mercado no mercado de licenciamento de sinal de televisão aberta para operadoras de SeAC}

134. Uma boa medida da força mercadológica dos canais das requerentes é audiência em TV por assinatura que habitualmente conseguem atrair vis-à-vis aquela que os seus congêneres retêm. Canais de maior audiência tendem a ter maior poder de mercado, implicando na capacidade de cobrar maiores preços e melhores condições de fornecimento do sinal em favor do vendedor.

135. Conforme apurado pela Superintendência-Geral do CADE, são as seguintes as participações no mercado relevante, segundo a audiência média alcançada em 2014:

$\begin{array}{cc}\text { Empresa } & \text { Market Share } \\ \text { Globo } & 58 \% \\ \text { Band } & 7 \% \\ \text { Cultura } & 0 \% \\ \text { Record } & \mathbf{1 6 \%} \\ \text { SBT } & \mathbf{1 6 \%} \\ \text { Rede TV! } & \mathbf{3 \%} \\ \text { Total } & 100 \%\end{array}$

Fonte: Ibope MW 2014.

136. A operação ocasiona participação conjunta de mercado de 35\%, ordem superior aos 20\% que a Lei de Defesa da Concorrência indica como suficiente a, em regra, gerar presunção de poder de mercado (art. 35, $\S 2^{\circ}$ ). ${ }^{53}$

137. Além disso, os dados da estrutura do mercado apontam que o índice Herfindahl-Hirschman (HHI) ${ }^{54}$ alcança atualmente 3.891 (três mil oitocentos e noventa e um) pontos. Um acordo de licenciamento conjunto de sinal por parte de Newco leva a uma concentração que atribuiria a este agente um market share de 35\%. O HHI subiria para 4.575 (quatro mil quinhentos e setenta e cinco) pontos. A variação seria de 684 (seiscentos e oitenta e quatro) pontos.

53 Art. 36, §2º: "Presume-se posição dominante sempre que uma empresa ou grupo de empresas for capaz de alterar unilateral ou coordenadamente as condições de mercado ou quando controlar $20 \%$ (vinte por cento) ou mais do mercado relevante, podendo este percentual ser alterado pelo Cade para setores específicos da economia".

54 Calculado pela soma dos quadrados dos market shares, o HHI tem ênfase em medir potencialidade lesiva de incremento de poder unilateral de mercado, vez que potencializa, mais que proporcionalmente ao incremento de shares, as maiores empresas. 
138. Para o Horizontal Merger Guidelines de 2010 da Federal Trade Commission e do Departamento de Justiça dos Estados Unidos, são altamente concentrados os mercados que ostentem HHI superior a 2.500 (dois mil e quinhentos) pontos. ${ }^{55}$ Além disso, são presumidos como aptos a reforçar de modo substancial poder de mercado as operações que impliquem em variação do HHI superior a 200 (duzentos) pontos. A presunção pode ser elidida apenas se condições estruturais do mercado assim indicarem.

139. Já a União Europeia considera no seu Guidelines on the assessment of horizontal mergers under the Council Regulation on the control of concentrations between undertakings (2004) $)^{56}$ que mercados com HHI acima de 2.000 (dois mil) pontos que tenham operações com variação acima de 150 (cento e cinquenta) pontos têm suficiente sinalização de incremento significativo de poder de monopólio.

140. Como todos os números de mercado e de impacto da formação da Newco são superiores ao parâmetro legal e aos parâmetros internacionais de $\mathrm{HHI}$, concluo que a operação em análise desperta preocupação concorrencial. Dessa forma, o ofertante que emerge dela terá novo poder que poderá ser usado em desfavor da maior eficiência estática e dinâmica do mercado. A seguir prossigo com a análise, examinando características de importação, barreiras à entrada, rivalidade e poder de compra compensatório para formar juízo sobre a probabilidade de exercício de poder de mercado.

\section{III.5. Probabilidade de exercício de poder de mercado no mercado de licenciamento de sinal de televisão aberta para operadoras de SeAC}

\section{III.5.1. Importação}

141. O vigente Guia SEAE-SDE para Análise Econômica de Atos de Concentração Horizontal indica que "As importações e a possibilidade de importar são fatores que inibem o exercício do poder de mercado. Quanto maior for a participação das importações elou a possibilidade de importar, menor será a probabilidade de que o poder de mercado seja exercido".

55 https:/www.ftc.gov/sites/default/files/attachments/merger-review/100819hmg.pdf, consulta em 26.04.2016.

56 http://eur-lex.europa.eu/legal-content/EN/TXT/PDF/?uri=CELEX:52004XC0205(02)\&from=EN, consulta em 26.04.2016. 
142. Os canais estrangeiros de televisão aberta têm reduzidíssima penetração no Brasil, o que nos leva a concluir que não são fonte de pressão concorrencial para as requerentes. A rigor, tais canais sequer são empacotados como programação de TV aberta, mas como canais étnicos ou internacionais o que indica outro mercado relevante. Os distribuídos no Brasil normalmente são públicos, muitas das vezes sequer com conteúdo em português. São exemplos DW, NHK, TVE, RTP, RAI, TV5.

143. Por tais características, considero que não é crível que importação seja fonte de pressão competitiva apta a limitar o poder de mercado decorrente da operação.

\section{III.5.2. Barreiras à entrada}

144. A facilidade de entrada é fator que torna o exercício de poder de mercado improvável. $\mathrm{O}(\mathrm{s})$ potencial(is) entrante(s) sinaliza(m) ao incumbente que, em caso de imposição de preço ao mercado, atrairá novos ofertantes ao mercado e da estratégia de incremento de lucratividade resultará perda de receitas e share de mercado. De modo absoluto, um mercado é dito contestável quando entrada é livre. Na prática a contestatibilidade de mercados é sempre uma questão de grau.

145. Para fins concorrenciais a entrada potencial que limita poder de mercado é aquela que seja provável, tempestiva e suficiente. É provável quando é economicamente lucrativa a preços pré-concentração, tempestiva quando possa ocorrer em até 2 (dois) anos e suficiente quando permitir que todas as oportunidades de venda sejam disputadas pelo entrante em potencial.

146. Um candidato a fornecedor de sinal programação de TV aberta para operadora de televisão por assinatura deve ser uma emissora de sinal de TV aberta. Excluída que foi a possiblidade de importação, vejo que no Brasil o processo para constituição e funcionamento de emissora aberta de televisão é custoso e certamente não permite entrada que se enquadre nos requerimentos exigidos pela práxis antitruste.

147. Primeiramente, é de sublinhar que, no interesse da diversidade de fontes e opiniões nos meios de comunicação de massa, ${ }^{57}$ há regramento

57 O parágrafo $5^{\circ}$ do art. 220 enuncia que "Os meios de comunicação social não podem, direta ou indiretamente, ser objeto de monopólio ou oligopólio". O caput e parágrafo primeiro estabelecem que "A manifestação do pensamento, a criação, a expressão e a informação, sob qualquer forma, processo ou veículo não sofrerão 
constitucional para a outorga ou renovação de concessão ou permissão que permita a entrada geradora de sinal de televisão. $\mathrm{O}$ ingresso de novo agente neste mercado só é possível por ato do Executivo que tenha anuência expressa do Congresso Nacional. $\mathrm{O}$ art. 223 da Constituição do Brasil estabelece que:

Art. 223. Compete ao Poder Executivo outorgar e renovar concessão, permissão $e$ autorização para o serviço de radiodifusão sonora e de sons e imagens, observado o princípio da complementaridade dos sistemas privado, público e estatal.

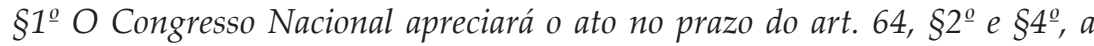
contar do recebimento da mensagem.

[...]

$\S 3^{\circ} \mathrm{O}$ ato de outorga ou renovação somente produzirá efeitos legais após deliberação do Congresso Nacional, na forma dos parágrafos anteriores.

148. É de quinze anos o prazo de concessão ou permissão de emissora de televisão. A não renovação depende da aprovação de dois quintos do Congresso Nacional, em votação nominal. ${ }^{58}$

149. No nível legal, as novas autorizações ou concessões para o serviço de radiodifusão de sons e imagens de natureza comercial devem ser precedidas de processo licitatório de modalidade concorrência, a modalidade mais completa, exigente e de maiores prazos. Deve haver lançamento de edital que contemple critérios de seleção destinados a garantir tratamento isonômico. Além disso, deve ser regido pelos princípios da legalidade, da moralidade, da impessoalidade e da publicidade, independentemente de manifestação anterior de interessado.

150. Não há prazo determinado para a realização de tais concorrências, sendo que elas são mais improváveis de ocorrer em mercados mais atrativos - os das grandes cidades - , vez que nestas a limitação física de canais se revela maior.

151. O número atual de outorgas de Televisão ativas no Brasil é 542, sendo 208 delas TVs educativas. ${ }^{59}$ Deve-se registrar que, do ponto de vista

qualquer restrição, observado o disposto nesta Constituição" e que "Nenhuma lei conterá dispositivo que possa constituir embaraço à plena liberdade de informação jornalística em qualquer veículo de comunicação social, observado o disposto no art. $5^{\circ}, I V, V, X$, XIII e XIV."

58 Art. 223, $\S 2^{\circ}$ e $\S 5^{\circ}$ da CRFB/1988.

59 Fonte ABERT, Raio X da Radiodifusão Brasileira. Tudo o que você precisa saber sobre rádio e televisão: licenças, outorgas, taxa de penetração, receitas, audiências e receptores. Maio/2015. p. 29. Disponível em: 
legal, as geradoras têm a mesma capacidade e podem produzir conteúdo próprio da forma que melhor lhes aprouver. Do ponto de vista puramente teórico, poderia ser um mercado altamente pulverizado, porém não é o que se observou historicamente. O número de concorrentes efetivos é bem menor restringe-se às cabeças de rede nacionais. Por existirem muitos ofertantes, mas poucos com capacidade de rivalizar é que se classifica este mercado como um oligopólio competitivo.

152. Diferentemente do que aconteceu com estações de rádio, as emissoras de televisões se organizaram no Brasil dominantemente na forma de grandes redes nacionais. Tais redes são formadas mediante contrato privado de licenciamento de programação. Por este contrato uma emissora, ela também uma concessionária local de televisão, se compromete a fornecer conteúdo a outra radiodifusora em troca de remuneração e outros compromissos. Neste arranjo, a compradora de programação se ocupa em retransmitir o conteúdo adquirido em sua localidade.

153. A estação que gera programação e licencia o seu uso por outras é chamada de cabeça de rede. A concorrência no mercado de sinal de televisão para operadoras de SeAC é basicamente entre estes cabeças de rede. Se a constituição de uma emissora de televisão qualquer já é uma tarefa difícil, o ingresso provável, tempestivo e suficiente de uma empresa que seja capaz de liderar rede de emissoras de televisão e disputar com os grupos já estabelecidos é dificílimo. Para ter sucesso, não prescinde da formação de alianças com emissoras presentes nos grandes centros urbanos do Brasil e em muitos destes não há sequer espaço de radiofrequência que comporte oferta maior do que a já existente.

154. Do ponto de vista histórico, a última vez em que se deu entrada significativa no mercado de cabeças de rede nacionais foi em 1999, quando o Grupo que hoje controla a Rede TV! adquiriu as cinco emissoras próprias da extinta TV Manchete (sediadas em São Paulo, Rio de Janeiro, Belo Horizonte, Fortaleza e Recife).

155. Além das dificuldades regulatórias de entrada, noto que é um setor com grande investimento inicial e altamente verticalizado. Uma entrante que deseje rivalizar com as requerentes deverá entrar simultaneamente nas

http://www.abert.org.br/web/index.php/bibliotecas/2013-05-22-13-32-13/category/pesquisas-sobreo-setor-de-radiodifusao, consulta em 28.04.2016. 
três etapas da cadeia de valor da televisão aberta, produção de conteúdo, programação e transmissão de conteúdo, vez que este é o padrão de concorrência deste mercado no Brasil. ${ }^{60}$

156. Ainda que logre entrar com sucesso na produção e na programação, poderá ter dificuldades em fincar pé no serviço de transmissão, eis que este é altamente dependente da exigência de disponibilidade de espectro de radiofrequência disponível. Em grandes cidades, justamente os mercados mais atraentes para auferir receitas publicitárias, as ocupações das frequências destinadas à radiodifusão tendem a ser maiores.

157. Com base nestas informações, observo que é altamente improvável a entrada de competidor com aptidão para limitar o poder de mercado reunido pelas requerentes a partir deste ato de concentração. Ainda, mesmo que fosse provável, noto que não seria, de modo seguro, tempestivo dada a irregularidade no lançamento de editais de concessão de radiodifusão e o tempo exigido pelas instâncias regulatórias de provedor deste tipo de serviço, que envolvem até mesmo o Congresso Nacional.

\section{III.5.3. Rivalidade}

158. A venda de sinal digital de TV aberta para operadora de SeAC é apenas uma das fontes de renda das radiodifusoras de sons e imagens - a mais recente e menos testada. A fonte tradicional é a publicidade, que tem relação com estratégias de mercado, nível de audiência e tipo de auditório que as geradoras conseguem alcançar. Quanto maior o potencial de audiência, maior a receita publicitária da programação. A lógica da indústria parece indicar que o preço do sinal para maior a operadoras de TV por assinatura também será uma função da audiência esperada. Dada a diferenciação intrínseca aos produtos e a menor importância desta receita no funcionamento histórico deste empreendimento, não me parece que esperada qualquer rivalidade em preços. ${ }^{61}$

60 Ancine registra que na Austrália e em países da Europa a distribuição das transmissões é feita pelos operadores nacionais de rede, de modo que os radiodifusores se concentram apenas na produção e programação. ANCINE, TV Aberta no Brasil: aspectos econômicos e estruturais. Observatório Brasileiro do Cinema e do Audiovisual - OCA -, 2015, p. 14.

61 Rivalidade em preços aqui significaria resposta agressiva da TV Globo ou da TV Band que limitasse a capacidade de elevação de preços decorrente da formação da Newco. 
159. A tendência para a ausência de rivalidade em preços é apontada pela Ancine em recente estudo sobre a TV aberta no Brasil..$^{62}$ Ainda que o estudo não tenha tido qualquer enfoque em atendimento de SeAC pelas televisões abertas, merece citação:

Contudo, a competição entre emissoras não parece se dar majoritariamente via preços, mas sim por tipo de programação a ser exibida e público-alvo a ser alcançado. Assim, os radiodifusores procuram produzir uma programação atraente ao maior número possível de espectadoras, em busca de maior audiência $e$, consequentemente, de uma maior quantidade de anunciantes interessados em financiá-los e um maior volume de recursos angariados com publicidade.

\section{III.5.4. Mercado de dois lados e poder de barganha de compradores}

160. Registro, contudo, que o potencial anticompetitivo se restringe unicamente à negociação de sinal digital de televisão aberta para operadora de SeAC. A principal dimensão de concorrência das geradoras de sinal de TV aberta cabeças de rede, que é a busca por audiência e receita publicitária via criação e/ou veiculação de conteúdo de interesse, não é afetada.

161. Mais do que isso, na linha do Parecer da Superintendência-Geral do CADE neste processo, o exercício de poder de mercado no campo da negociação de sinal para operadora de SeAC pode gerar efeitos indesejados na busca por audiência e receita publicitária. Isto aconteceria no caso de a Newco impor condições comerciais não aceitas pelas operadoras.

162. A falta de acesso ao line-up das provedoras de televisão por assinatura acarretaria redução do potencial de audiência e de nada adiantaria um conteúdo atrativo se o assinante não o assistisse. Sendo a publicidade a maior receita das sócias da Newco, uma estratégia de exagerada elevação de preços do sinal negociado com as operadoras de TV por assinatura poderia ser contraproducente.

163. O raciocínio deve ser visto como uma tendência comportamental e não um juízo absoluto, vez que a parcela de assinantes de TV por assinatura

62 ANCINE, TV Aberta no Brasil: aspectos econômicos e estruturais. Observatório Brasileiro do Cinema e do Audiovisual - OCA -, 2015, p. 27. 
que não acessar o(s) canal(is) via set top box de operadora de SeAC pode desejar assisti-lo(s) a partir da transmissão realizada diretamente pelas radiodifusoras. O nível de audiência que alcança as TVs abertas nos serviços de TVs por assinatura revela, porém, que não é desprezível o aspecto econômico comportamental associado à comodidade que os telespectadores associam a ter um canal de TV aberta no line-up de uma cable. Tirar a visibilidade do canal para um assinante em muitos casos certamente se converterá em perder potencial de audiência e receita publicitária.

164. O prejuízo em receitas publicitárias seria tanto maior quanto o tamanho da base de assinantes da empresa que não chegasse a acordo com a Newco. Neste sentido, é destacada a capacidade de limitação do exercício de poder de mercado da Newco por parte das grandes operadoras, Net e Sky, e reduzida a capacidade de pequenas operadoras imporem limites.

165. Por fim, noto que a Lei $\mathrm{n}^{\mathrm{o}}$ 12.485/2011 atualmente prevê o direito de radiodifusoras imporem às operadoras de televisão por assinatura carregamento do sinal em caso de desacordo comercial (art. 32, §13). ${ }^{63}$ É uma faculdade legal que assegura que a(s) radiodifusora(s) não sofra(m) o prejuízo decorrente de perda de potencial de audiência, se assim desejar.

166. Não é certo, porém, que o resultado desta barganha deva o sinal ser sempre oferecido gratuitamente em qualquer caso de desacordo. A remuneração ou não do sinal ou do conjunto de sinais dependerá de quanto a operadora de TV por assinatura perceba que o(s) canal(is) agrega(m) de demanda ao seu serviço. Caso haja a perda de assinantes pela falta de um ou mais canais no line-up, a(s) radiodifusora(s) pode(m) se dispor a sonegar sinal e enfrentar perda de receita por algum tempo, antevendo a disposição a pagamento por parte da operadora de SeAC em algum prazo futuro.

\section{III.6. Dos estudos econômicos}

167. No sentido de compreender melhor os efeitos da operação no mercado relevante em questão, elaboramos estudos econômicos que pudessem apresentar um diagnóstico acerca da operação. Para tanto, escolhemos modelos

63 “Caso não seja alcançado acordo quanto às condições comerciais de que trata o §12, a geradora local de radiodifusão de sons e imagens de caráter privado poderá, a seu critério, exigir que sua programação transmitida com tecnologia digital seja distribuída gratuitamente na área de prestação do serviço de acesso condicionado, desde que a tecnologia de transmissão empregada pelo distribuidor e de recepção disponível pelo assinante assim o permitam, de acordo com critérios estabelecidos em regulamentação da Anatel". 
econométricos que pudessem, ainda que não exatamente, representar mais próximo possível a realidade do mercado, indicando qual seria o provável impacto da JV para o consumidor final, de maneira a endereçar quais seriam medidas necessárias e suficientes para dar conforto a uma eventual aprovação da operação. $\mathrm{O}$ conforto aqui mencionado pode ser entendido como sendo a compensação de eventuais prejuízos concorrenciais por meio da adoção de remédios comportamentais que enderecem as preocupações levantadas em todo o voto.

168. Cumpre destacar que, muito embora a conselheira Relatora tenha envidado esforços no sentido de demonstrar a probabilidade de exercício de poder de mercado e dos efeitos anticompetitivos da operação, não consta em nenhuma parte do voto qualquer estudo econométrico específico da operação que possa atestar a tese por ela alegada. Toda a argumentação que ampara seu ponto de vista deriva de análise intuitiva dos princípios e fundamentos econômicos, sem, contudo, aprofundar em nenhum dos temas.

169. O que tentamos fazer no momento é testar se os pontos, principalmente os relacionados ao aumento de preço para o consumidor final, defendidos intuitivamente pela conselheira Relatora são de alguma forma comprovados pelos testes econométricos.

170. Sendo assim, utilizamos os seguintes modelos: para efeitos unilaterais: (i) Gross upward pricing pressure, GUPPI (efeitos unilaterais com produtos diferenciados); e Coordinated Price Pressure Index, CCPI (efeitos coordenados com produtos diferenciados). O GUPPI é um índice, reportado em termos percentuais, que deve ser interpretado como "o percentual de eficiências requeridas para que a operação compense totalmente seu upward price pressure (UPP). O CPPI é um índice que aponta qual o aumento percentual de preço que pode ser obtido para diferentes estruturas de mercado (antes e depois de qualquer operação de concentração), sob condições de colusão tácita. Um $\triangle$ CPPI positivo (sugere que a concentração aumentará a probabilidade para Parallel Accomodating Price - PAC). Por outro lado, um $\triangle$ CPPI negativo (sugere que a concentração reduzirá a probabilidade para PAC). Finalmente, um $\triangle$ CPPI nulo sugere que a concentração não altera os incentivos.

171. O objetivo do estudo é simular eventuais pressões para aumento de preços (efeitos unilaterais) e de incentivos para maior grau de coordenação tácita (efeitos coordenados), decorrentes da formação da joint venture composta pelas empresas SBT, Record e Rede TV. São também simulados a pressão de preços decorrentes de dupla margem envolvendo a licenciadora JV (upstream) e as empresas de distribuidoras de conteúdo de TV fechada (downstream). 
Importante analisar os resultados com cautela, pois seus resultados são muito sensíveis a depender das hipóteses concorrenciais e dos valores dos parâmetros para simulação.

\section{Primeiro passo: efeitos unilaterais e simulação com modelo GUPPI (Gross upward pricing pressure)}

172. O primeiro passo consistiu em uma simulação para fusões. A partir dos dados de market share das partes e de seus concorrentes, foram computadas simulações para potenciais pressões de preços decorrentes da concentração. Foi assumido que a operação envolvia um ato de concentração clássico (fusão) e os competidores pertencentes ao mercado relevante delimitado concorreriam em preços, ou seja, por meio de um modelo de concorrência de Bertrand. Os diferenciais de preços entre os concorrentes foram parametrizados a partir dos custos de anúncio de comerciais (30 segundos) de todos os programas das grades de todos os concorrentes (dados coletados em sítios eletrônicos especializados). Foram construídos três cenários: (i) diferenciais entre os preços por 30 segundos nos programas mais caros; (ii) diferenciais entre os preços por 30 segundos nos programas mais econômicos; (iii) diferenciais a partir dos preços medianos. A partir das estimativas de GUPPI para cada um dos cenários, foi construída uma distribuição de 'pequeno porém significativo e não transitório' aumento de preços dentro de um intervalo entre $2 \%$ e $6 \%$ (sem desconto de qualquer eficiência).

\section{Modelo GUPPI (Parâmetros da Simulação)}

\begin{tabular}{|c|c|c|c|}
\hline Variáveis & & Valores dos Parâmetros & Modelo \\
\hline elasticidade & $=$ & 2 & \\
\hline margem x elasticidade & $=$ & 1.00 & Cortrand \\
\hline Margem de lucro & $=$ & 0.50 & \\
\hline Preço & $=$ & 100.00 & \\
\hline Taxa de juros anual & $=$ & 0.10 & \\
\hline Quantidade & $=$ & market share & \\
\hline Fator de desconto & $=$ & 0.91 & \\
\hline
\end{tabular}


173. A partir dos parâmetros acima definidos chegamos aos seguintes resultados.

\section{Cálculo do GUPPI (Eficiências Requeridas)}

\begin{tabular}{|c|c|c|c|c|c|}
\hline & DE & PARA & VALOR & $\%$ & SSNIP \\
\hline GUPPI & SBT & Rec+RTV & 0.11 & $11.2 \%$ & $5.6 \%$ \\
\hline GUPPI & Rec+RTV & SBT & 0.14 & $14.4 \%$ & $7.2 \%$ \\
\hline
\end{tabular}

174. O índice GUPPI variou entre 5,6\% e 7,2\%. Trata-se de um percentual de eficiências requeridas compatíveis com operações de riscos concorrenciais pouco significativos, não apresentando, portanto, preocupação quanto a probabilidade de diminuição do bem-estar do consumidor. Conquanto, ainda que se possa entender que a pressão de preço é significativa, basta demonstrar a existência de eficiências suficientes para suplantar um aumento de $5.6 \%$ ou $7.2 \%$, o que não nos parece difícil como veremos adiante.

Segundo passo: simulação dupla margem

175. O segundo passo consistiu em um exercício de simulação de dupla margem, com base nos parâmetros da tabela abaixo.

\section{Dupla Margem (Parâmetros)}

\begin{tabular}{|l|r|}
\hline Preço & 100.00 \\
\hline Custo Total & 65.00 \\
\hline Margem Bruta & 0.35 \\
\hline Market Share partes & 0.32 \\
\hline Razão "custos assinaturas TVs abertas/custos assinaturas totais & 0.20 \\
\hline
\end{tabular}

176. A primeira margem seria decorrente do aumento de preços da fusão, ou seja, dos preços do sinal da TV aberta para as distribuidoras. Aqui foram construídos dois cenários: (i) um aumento de 5\%; e (ii) um aumento de $10 \%$. 
Considerando o fato de que as simulações de "pequeno porém significativo e não transitório" aumento de preços ficaram dentro de um intervalo entre $2 \%$ e $6 \%$, o cenário de um aumento de $5 \%$ é o mais provável.

177. A segunda margem deriva de um repasse dos custos adicionais, decorrentes do aumento do preço do sinal de TV aberta pela distribuidora (supostamente monopolista), ao consumidor final. É assumido que o distribuidor opera com um mark-up fixo de $35 \%$ sobre os custos marginais. Os custos marginais são compostos pela soma do valor da compra do sinal (TV aberta ou fechada) e demais custos. Aqui são assumidos três cenários: que os custos com compras de sinais (TV aberta ou fechada) correspondem por $25 \%, 50 \%$ e $75 \%$ dos custos marginais totais da distribuidora. Adicionalmente, são construídos diferentes cenários para a participação do custo com sinal de TV aberta sobre os custos totais com compra de sinal (TV aberta + TV fechada): $20 \%, 35 \%, 50 \%$ e $75 \%$. O valor mediano (da distribuição dos valores obtidos nos vários cenários) do aumento de preço final aos consumidores foi de $8 \%$.

$$
\text { Simulação Dupla Margem (Parâmetros e Resultados) }
$$

\begin{tabular}{|l|r|}
\hline Preço & 100.00 \\
\hline Custo Total & 65.00 \\
\hline Margem Bruta & 0.35 \\
\hline Market Share partes & 0.32 \\
\hline Razão custos assinaturas TVs abertas/custos assinaturas totais) & 0.20 \\
\hline Cenário mais favorável para a operação & $1,7 \%$ \\
\hline Cenário menos favorável para a operação & $17, .2 \%$ \\
\hline
\end{tabular}

178. Contudo, há de se considerar que o exercício acumula um conjunto de hipóteses bem conservadoras, mesmo desenhando diferentes cenários. Também não é assumido que a operação traga qualquer eficiência que possa endereçar a pressão por aumento de preços. 


\section{Terceiro Passo: Efeitos coordenados e simulação com modelo CPPI (Coordinated Price Pressure Index)}

179. Neste caso testamos se uma eventual fusão das partes envolvidas na operação poderia trazer alguma pressão de aumento de preços por meio de efeitos coordenados, ou seja, um aumento no incentivo para paralelismo de preços entre concorrentes. Os resultados de simulações a partir do modelo de CPPI mostraram que o mercado não apresenta incentivos para paralelismo (entre as emissoras SBT, Record, RedeTV e Rede Globo, a maior concorrente e maior player do mercado) e tais incentivos permaneceriam inalterados mesmo com uma eventual fusão entre as partes.

\section{Cálculo do CPPI E $\Delta$ CPPI}

\begin{tabular}{|c|c|c|c|c|c|}
\hline \multicolumn{6}{|c|}{ ANTES } \\
\hline INICIA & Termo F & Termo $\Theta$ & $\mathrm{S}_{1}$ & $\mathrm{~S}_{2}$ & CPPI \\
\hline SBT & 1.198 & 0.000 & -6.124 & -2.753 & -6.124 \\
\hline Globo & 0.166 & 0.000 & 0.089 & 0.090 & 0.089 \\
\hline \multicolumn{7}{|c|}{ DEPOIS } \\
\hline INICIA & Termo F & Termo $\Theta$ & $\mathrm{S}_{1}$ & $\mathrm{~S}_{2}$ & CPPI \\
\hline SBT & 1.198 & 0.000 & -6.124 & -2.753 & -6.124 \\
\hline Globo & 0.468 & 0.000 & 0.371 & 0.401 & 0.371 \\
\hline \multicolumn{7}{|c|}{ Delta CPPI } & & 0.000 & \\
\hline
\end{tabular}

180. Ao observarmos os estudos acima, percebemos que o único teste que está em consonância com as conclusões intuitivas do voto da conselheira Relatora é o terceiro passo, de maneira que há convergência quanto à ausência de probabilidade de existência de pressão de aumento de preços por meio de efeitos coordenados.

181. Quanto aos demais, o que se pode perceber é que a análise quantitativa nos leva a conclusões diametralmente opostas daquelas expressas no voto do relator, principalmente quando comparado ao caso americano importado pela conselheira, cujo resultado sugeriria uma pressão de preço de até $40 \%$. 
182. Nesse sentido, conclui-se que os estudos econométricos não confirmaram as preocupações concorrenciais imaginadas, principalmente quanto a diminuição do bem-estar do consumidor. Ao contrário, restou demonstrado que mínimas eficiências apresentadas pela operação podem suplantar eventuais prejuízos e gerar, ao contrário do que foi dito, aumento de bem-estar para o consumidor final.

\section{III.7. Eficiências alegadas inicialmente}

183. Como ocorre em grande parte dos atos de concentração, a presente operação, como demonstrado neste voto e também pela Conselheira Relatora, gera uma restrição à concorrência, o que é um custo para a sociedade, tendo em vista o potencial para geração de peso-morto, má alocação de recursos, aumento de custos para os consumidores, dentre outros. Contudo, a análise não se encerra neste ponto, pois é preciso verificar se as eficiências intrínsecas à operação compensam esses custos. Nesse sentido, como bem observado pela Conselheira Relatora, em consonância com o referido guia da SEAE/ SDE:

226. São consideradas eficiências econômicas apenas os incrementos específicos da operação, ou seja, aquelas que aumentam o bem-estar social e que não podem ser geradas de outra forma senão pelo AC. Estes incrementos de eficiência são difíceis de se verificar e quantificar, em parte porque a maior parcela da análise refere-se a projeções ou a eventos futuros, que podem não se concretizar - ainda que haja boa-fé das Requerentes quando da apresentação do caso ao Cade. Serão consideradas eficiências específicas, por isso, aquelas cuja magnitude e possibilidade real de ocorrência possam ser constatadas por meios razoáveis, estando bem descritas e especificadas. A objetividade, portanto, é imprescindível, e números concretos, plausíveis e críveis são primordiais.

227. Seria um erro aceitar alegações meramente especulativas ou vagas. Como "querer não é poder" e como muitas vezes os planos estratégicos, desenhados com minuciosos detalhes pelas empresas, são frustrados por eventos futuros não esperados, meras opiniões, desejos ou crenças serão obviamente desconsideradas.

184. Revisito a análise das eficiências alegadas no momento inicial das tratativas da operação, ainda antes do voto da Conselheira Relatora, que foram: (1) obtenção de receitas que seriam revertidas em investimentos para 
aumento da oferta e da qualidade de conteúdo; (2) incentivo para investir a receita adicional em prol do consumidor final; (3) geração de empregos; (4) futuramente, possibilidade de produção de conteúdo audiovisual distinto daquele ofertado pelas Requerentes em TV aberta (licenciamento de canais pagos), com ampliação do fornecimento de conteúdo nacional ao público; (5) otimização de custos com a criação de área comercial especializada na negociação e licenciamento de canais junto às operadoras; (6) geração de poder compensatório das emissoras de TV aberta em relação às operadoras.

185. Sobre o primeiro item, as receitas que seriam obtidas com a JV para investimentos consistiriam em mera transferência de recursos, sendo que o potencial maior de investimento das emissoras equivaleria a um menor investimento por parte das operadoras. Sem uma justificativa plausível para isso, bem como na ausência de um plano de negócios, o argumento deve ser rejeitado.

186. O segundo item, basicamente um subconjunto pertencente ao primeiro, refere-se ao incentivo para o investimento com a receita marginal obtida pela JV, em prol dos consumidores. Novamente, seria necessário haver uma justificativa, incluindo um plano de negócios robusto, para aceitar essa transferência de renda entre operadoras e/ou consumidores para as emissoras. Além disso, seria necessária a garantia, e não mero argumento de incentivo, que esse ganho adicional, ou parte significativa dele, efetivamente seria revertido em prol dos consumidores. Como argumentado pela Conselheira Relatora,

245. Se, individualmente, não houve supostamente "incentivo em investir" em conteúdos mais atrativos, mesmo com crescimento da receita, por que este "incentivo" mudaria com a JV, sendo que, originariamente, apenas [acesso restrito ao CADE e Requerentes] do faturamento da JV ficará nesta empresa e que sua concretização era incerta [...].

187. Igualmente rejeitado deve ser o item 3, visto que a geração de empregos deve ser uma consequência do aumento de produtividade da economia, e não um fim último do direito concorrencial. Toda a preocupação estatal com a concorrência e com os consumidores decorre do aumento do bem-estar da sociedade, obtido pelo aumento da produtividade. Com esse aumento, o que tende a se refletir em preços menores ao consumidor, além de beneficiar esta classe de agentes econômicos, também tende a refletir, com o aumento do número de transações, em aumento de empregos, de arrecadação de impostos, de lucros, enfim, de desenvolvimento socioeconômico. 
188. No que tange ao item 4, qual seja, a possibilidade de a JV vir a atuar na produção de conteúdo audiovisual distinto daquele ofertado pelas Requerentes em TV aberta, ampliando o fornecimento de conteúdo nacional ao público, seria uma potencial fonte de eficiências que poderia compensar a concentração decorrente da operação. Contudo, as Requerentes originariamente colocaram esse item apenas como uma possibilidade futura, sem qualquer expectativa concreta sobre sua implementação. Este deve ser um importante capítulo do remédio negociado. Para efeitos deste capítulo de análise de eficiências que justificariam a aprovação da operação sem restrições, a alegação deve ser descartada.

189. Quanto ao item 5, que trata da otimização de custos com a criação de área comercial especializada, eventuais ganhos de eficiência e redução de custos de transação são ínfimos, visto ser uma atividade que não exige maiores investimentos e em que há uma relativa facilidade na contratação de bons profissionais. Além disso, novamente as Requerentes falharam em apresentar um plano de negócios concreto.

190. Quanto ao item 6, referente à tese do poder compensatório, assim como feito pela Conselheira Relatora, aprofundo mais sobre o tema. Desconsiderando-se essa tese, bem como outras potenciais eficiências, não caberia à autoridade antitruste ajustar os ganhos de cada agente do mercado, de modo a buscar uma distribuição mais equânime. É a escassez de cada produto ou serviço, ou seja, a relação entre oferta e demanda, resultante do processo competitivo, que deve determinar os preços no mercado, o que incentiva o aumento da oferta e a redução da demanda para produtos escassos, e o inverso para produtos em abundância. Com isso, na ausência de falhas de mercado, e com a presença de concorrência, tende-se a chegar a um equilíbrio socialmente benéfico. Ressalte-se, novamente, o termo concorrência.

191. Não sem razão, como apresentado pela Conselheira Relatora, nos EUA, a mera negociação conjunta entre as maiores radiodifusoras geraria efeitos negativos para o mercado:

Diante da Revisão Regulatória Quadrienal conduzida pela FCC (Federal Communications Commission) [62], o DoJ sustentou perante esse órgão regulador que a negociação conjunta do retransmission consent entre uma ou mais radiodifusoras deve ser considerada infração antitruste per se, diante da possibilidade de elevação de preço para o consumidor final. Para o DoJ, por isso, a análise pela regra da razão torna-se desnecessária neste caso. Ela só se justificaria quando a venda conjunta resultasse em aumento de eficiência e não 
no aumento do poder de barganha com o outro elo da cadeia produtiva. Aliás, a mera redução de custos de transação sequer é aceita pelo DoJ como uma eficiência neste caso.

192. Na forma como apresentada, assiste razão à Conselheira Relatora. Não se questiona que a pura coordenação, naked, entre as emissoras, desprovida de eficiências e de eventual poder compensatório, meramente resultando em uma redução da pressão competitiva, geraria uma perda de bem-estar para a sociedade. Trata-se de um entendimento pacífico na teoria antitruste.

193. A pergunta é se eventual incremento de poder de mercado das Requerentes com a criação da JV compensaria um suposto exercício do poder de mercado preexistente pelas duas operadoras líderes de televisão por assinatura. A Conselheira Relatora entendeu que não. Primeiro argumentou que a nova regulação já garantiria um poder adicional para as emissoras, tendo em vista a possibilidade de imposição de must carry. Segundo, argumentou que teoricamente o argumento não faria sentido, nos seguintes termos:

É uma premissa desprovida de fundamentação econômica. As operadoras só não aumentarão o preço dos pacotes para o CF, se a elasticidade-preço do $C F$ for altíssima, que não é o caso, segundo as próprias Requerentes. Se fosse, o ajuste seria em outro lugar, possivelmente em uma redução na oferta de canais, o que também diminuiria o bem-estar do CF. Uma empresa que tem aumento de custo vai tentar repassá-lo adiante, justamente para não diminuir a sua margem. Faz parte de qualquer negócio e seria estranho que as operadoras não tentassem fazer isso.

194. Ressaltou ainda que essa teoria não seria bem aceita nem nos EUA, nem na Europa, nem no âmbito da OCDE, tendo relevância marginal nas distintas jurisdições. Apenas para o poder compensatório na compra de insumo, haveria alguma literatura reconhecendo a possibilidade de ganhos sociais decorrentes do poder compensatório. Após um exercício teórico, a Conselheira conclui que:

Diante da realidade brasileira, sem embargo, onde há mercados com muitas idiossincrasias e peculiaridades regulatórias - que abarrotam o Cade com condutas colusivas, face a um poder de mercado preexistente -,é importante trazer este tema à mesa. Conquanto seja um assunto marginalizado em outras jurisdições - o que já é um forte indício de que os resultados positivos do 
poder compensatório sejam improváveis -, uma bem fundamentada reflexão no âmbito do Cade é meritória. Se por um lado, discutir sob a luz da teoria econômica pode trazer ações mais precisas por parte dessa autarquia, por outro, a prática pode confirmar o que as outras jurisdições vêm afirmando: não vale perder tempo com este tema. A ver, pois.

No presente AC, esta JV se assemelha à situação (1b), em que o poder compensatório ocorre no mercado a montante pelas TVs abertas (venda do insumo: transmissão do conteúdo da TV aberta), frente a um mercado a jusante (compra deste conteúdo) concentrado, formado pelas operadoras. O resultado previsto, de acordo com as hipóteses feitas, é o do duplo mark-up, com perdas de bem-estar para o CF.

195. Por fim, a Conselheira Relatora expressa sua preocupação com a franja das operadoras, nos seguintes termos:

Além disso, o modelo teórico desconsidera os potenciais efeitos deletérios sobre a franja das operadoras e sobre os potenciais entrantes neste mercado, em que ambos agentes têm cumprido um papel fundamental no processo de massificação do serviço e na diminuição do exercício do poder de duopólio em algumas regiões. Se a assimetria regulatória ocorre sem a JV, a atuação conjunta de três importantes TVs abertas agravaria a situação, podendo resultar em falência destas empresas e no consequente aumento da concentração entre as Net e Sky.

196. Acompanho o entendimento da Relatora, mas teço alguns comentários sobre alguns pontos. A tese do poder compensatório efetivamente é pouco aceita na literatura antitruste, em especial quando comparada a outras teorias, como a dos efeitos negativos decorrentes da formação de cartel. Contudo, trata-se de um tema novo, em que o atual conhecimento econômico ainda é vacilante sobre seus efeitos, o que é normal. Por exemplo, restrições verticais já foram consideradas ilegais per se nos EUA, passando a uma análise pela regra da razão, chegando mesmo, segundo alguns, a uma presunção de legalidade.

197. Ainda nos EUA, mesmo que marginal, o Guia de Colaboração entre Competidores do FTC admite a possibilidade de acordos entre competidores para negociação coletiva de seus produtos em situações específicas, como aquele relatado no Exemplo 4 do manual. O exemplo se refere a duas start ups produtoras de software formada por sócios sem qualquer experiência em 
comércio, gestão ou marketing que fazem uma joint venture para negociar melhores condições e colocação dos seus produtos no mercado, fazendo parte do acordo a combinação de preço e negociação coletiva. O guia afirma que acordo entre competidores que tendem a aumentar preços ou restringir a oferta é sempre ou quase sempre ilícito per se, a não ser que esteja razoavelmente relacionado ou seja necessário para alcançar benefícios pró-competitivos em virtude de um incremento de eficiência advindo para atividade econômica. ${ }^{64}$ De fato, o exemplo não é exatamente igual ao da presente $\mathrm{JV}$, conquanto o importante não é saber se o caso é literalmente idêntico ao americano, mas sim se suas características principais se fazem presentes. Necessário se faz identificar as circunstâncias assemelhadas entre o fato concreto e o exemplo dado e, a partir daí, extrair da norma o seu melhor significado para, só então, concluir pela coerência de sua subsunção.

198. Outro exemplo de jurisdição estrangeira que admite a possibilidade de barganha coletiva e de acordo entre competidores acerca das condições de mercado é a autoridade antitruste australiana. Conforme disposto no sítio da entidade, 65 "É ilegal empresas competidoras se juntarem para acordar seus preços (ou para acordar a cobranças de taxas). Fixação coletiva de preços não precisa ser escrita - um acordo verbal ou um entendimento informal é suficiente. Empresas podem solicitar à ACCC autorização para praticarem essa conduta, caso eles considerem que haverá benefícios públicos." (Tradução própria)

199. Importante destacar que a autoridade antitruste australiana não trata o tema marginalmente, ao contrário, atribui a ele a sua devida importância, uma vez que institui dois procedimentos distintos para chancelar esse tipo de acordo ou conduta, senão vejamos. Os procedimentos são: autorização e notificação. Conforme consta nas normas que regulamentam os procedimentos, a autorização pode ser concedida em algumas situações, dentre as quais destaco as seguintes: "barganha coletiva - por exemplo quando empresas pequenas negociam termos e condições com grandes consumidores ou grandes fornecedores; $e$

64 Net-Business and Net-Company will agree on the prices at which NET-FIRM will sell their individuallyproduced software. The agreement is one "not to compete on price," and it is of a type that always or almost always tends to raise price or reduce output. The agreement to jointly set price may be challenged as per se illegal, unless it is reasonably related to, and reasonably necessary to achieve procompetitive benefits from, an efficiency-enhancing integration of economic activity. (ANTITRUST GUIDELINES FOR COLLABORATIONS AMONG COMPETITORS - FTC/DOJ)

65 https://www.accc.gov.au/business/pricing/setting-prices - "It is illegal for competing businesses to get together and agree to fix their prices (or to agree to charge certain fees). Price fixing agreements don't need to be in writing - a verbal agreement or an informal understanding is sufficient. Businesses can apply to the ACCC for authorisation to engage in this conduct if they consider it provides a public benefit." 
2) certas joint ventures ou alianças - por exemplo um acordo de fornecedores onde um competidor deixa de produzir determinados produtos para então comprá-lo da outra parte" 66 (tradução própria). O procedimento de notificação se diferencia da autorização tendo em vista algumas características específicas como a identificação de todos os membros que fazem parte da barganha coletiva e não tendem a mudar com o tempo, tem um alvo específico que o grupo deseja negociar coletivamente, existe um valor máximo do ganho em que cada membro do grupo poderá ganhar anualmente e a negociação não pode durar por mais de três anos. ${ }^{67}$

200. O objetivo a apresentar os procedimentos acima é demonstrar que à matéria é dada a sua devida importância pela comunidade antitruste internacional e não é tratada de forma marginal. As referidas autoridades identificam possibilidade de eficiências e benefícios à coletividade em barganhas coletivas justamente assumindo a "tese do poder compensatório" diminuindo assimetria de poder de mercado entre as partes nos dois polos dos mercados upstream e downstream. Se assim não fosse tratariam todo e qualquer tipo de conduta desse tipo com presunção juris et de jure e não criariam procedimentos que possibilitassem a comprovação de eficiências.

201. Sendo assim, entendo que a tese do poder compensatório tem seu valor e pode sim ser aplicada em casos muito específicos, mas não na forma apresentada pelas requerentes. Nesta esteira, gostaria de ressaltar que o trato com o tema merece cautela, tendo em vista o desenvolvimento aquém do desejável do conhecimento científico. Assim acompanho em parte o entendimento da Conselheira, que afirmou que "[c]onquanto seja um assunto marginalizado em outras jurisdições - o que já é um forte indício de que os resultados positivos do poder compensatório sejam improváveis -, uma bem fundamentada

66 https://www.accc.gov.au/business/applying-for-exemptions/authorisation - Businesses can seek authorisation to engage in arrangements or conduct that may breach the competition provisions in the Act (except for misuse of market power). The types of arrangements the ACCC is often asked to authorise include: collective bargaining - for example where small businesses negotiate terms and conditions with a large customer or supplier; [...] certain joint ventures or alliances - for example a supply agreement where one competitor agrees to stop producing a particular product and instead purchase it from the other party.

67 https://www.accc.gov.au/business/applying-for-exemptions/notifications - Collective bargaining is an arrangement where two or more competitors come together to negotiate terms and conditions (which can include price) with a supplier or a customer (the target). The notification process is likely to be more suitable than lodging an application for authorisation for a proposed collective bargaining arrangement when: all members of the bargaining group are identified and are unlikely to change over time, there is a single supplier or customer (target) with whom the group wishes to negotiate, the annual value of the transactions each member of the bargaining group will have with the target under the collective arrangement is not greater than $\$ 3$ million (the transaction threshold differs for some industries), the exemption under the Act is required for less than three years. 
reflexão no âmbito do Cade é meritória", mas ressaltando que não se trata de um assunto marginalizado. Prefiro utilizar termo mais apropriado para caracterizar a preocupação das demais jurisdições. Trata-se de tema especial, destinado a situações específicas e não corriqueiras, como é o caso em concreto. Concordo ainda com a Conselheira Relatora quando afirma que uma bem fundamentada reflexão no âmbito do Cade é meritória, assim como é feito em jurisdições mais experientes que a nossa.

202. Ante o exposto, entendo que a operação poderia apresentar eficiências que poderiam compensar a restrição à concorrência. Contudo, da forma como ela foi apresentada, esses ganhos seriam ínfimos, bem como houve uma quase que absoluta falta de concretude sobre como, e se, seriam implementadas essas ações que seriam desejáveis de um ponto de vista social. Dessa forma, acompanho a Conselheira Relatora no sentido da ausência de eficiências intrínsecas à operação na forma originariamente apresentada.

\section{I.8. Das manifestações de terceiros acerca dos remédios negociados em ACC}

203. Quando indagados de modo final acerca de aspectos gerais da operação e de remédios cabíveis e negociados para o ato de concentração, as terceiras expuseram as seguintes considerações.

204. Claro-Net NET (SEI 0197563) se manifestou contrariamente a qualquer remédio com base no argumento de que os cogitados seriam estritamente comportamentais e possivelmente extrapolariam competência do CADE.

205. A Sky também se opôs aos termos de remédios então negociados, porque (SEI 0194759):

a) Nos termos de parecer elaborado pela GO Associados acerca de remédios adotados na jurisprudência do CADE e sugeridos pela International Competition Network, "os danos concorrenciais causados pela joint venture entre as emissoras TV SBT, Record e Rede TV submetida ao Cade não são passíveis de neutralização através dos remédios antitruste conhecidos na literatura jurisprudência do Cade". Segundo estudo juntado aos autos, "os remédios existentes ou são inócuos para mitigar os danos concorrenciais causados pela operação de criação da joint venture entre as emissoras TV SBT, Record e Rede TV, ou geram outros problemas que impedem sua aplicação eficaz nesta operação". Eventuais remédios 
"têm o custo de monitoramento elevado, causando conflito com o órgão regulador do setor e não eliminam o problema de fato, que é o aumento do preço ao consumidor final".

b) Sobre obrigações de investimento em conteúdo novo, criação de assimetrias em favor de pequenos operadores de TV por assinatura, definição de uma mecânica que inviabilize repasse de preços a consumidor final ou limitação temporal da joint venture, entendem que as proposições sequer são remédios, o que dirá remédios relacionados especificamente aos malefícios da operação pretendida. No máximo seriam paliativos que desconsiderariam a complexidade do contexto econômico pertinente.

206. A ABTA também foi contrária a qualquer remédio porque (SEI 0194735):

a) mudança de objeto da Newco, de modo a aumentar importância da produção de conteúdo, demandaria uma nova notificação ao CADE. Ainda que não notificada, a alteração seria ineficiente por conta de saturação do mercado e favorecimento a conteúdo de produção independente (com produtoras desvinculadas de radiodifusoras).

b) A produção de conteúdo para canais de TV aberta não seria eficiência específica da operação, pois alcançável por qualquer dupla de empresas que queira efetuar investimentos conjuntos, que não seriam dependentes da negociação conjunta dos sinais já existentes.

c) O estabelecimento de cláusulas mais favorecidas para aquisição de conteúdo por parte de médias operadoras de TV por assinatura não impediria coordenação de preços das requerentes e anularia a possibilidade de discriminação de preços de segundo grau (por volume).

d) A aceitação de obrigação de must offer por parte das Requerentes em benefício de pequenos operadores seria contrária a opção legislativa de fim desta obrigação a partir do desligamento do sinal analógico de televisão.

e) Uma obrigação de preço fixo não impediria o repasse deste para o consumidor final, já que operadoras de televisão por assinatura definem preços tendo em conta o custo total médio e não o custo marginal.

f) A limitação temporal da Newco não diminuiria os impactos negativos esperados para o mercado.

g) Os remédios negociados gerariam contradição com opções regulatórias de Anatel e Ancine.

207. A Neo TV, por sua vez, se manifestou favoravelmente a obrigações de must offer de programação da SBT, Record e Rede TV! em favor de pequenas operadoras de televisão por assinatura (SEI 0194635). Entendem que a 
desproporção da força de barganha entre suas associadas e as requerentes é preexistente e apenas se agravaria caso não houvesse o estabelecimento de obrigação deste tipo.

\section{II.9. Das restrições que endereçam os problemas concorrenciais}

208. Verifica-se, em suma, que a pretensão da Newco de negociar conjuntamente sinais das geradoras cabeça de rede SBT, Record e Rede TV! tende a: (i) elevar o poder de mercado das Requerentes e (ii) implicar no seu exercício, tendo em vista limitações para importação de bens substitutos, barreiras à entrada de novos agentes e baixa rivalidade em preços. Por outro lado, há uma expectativa de que os grandes compradores de canais para TV por assinatura, especificamente Net e Sky, tenham alguma capacidade de obter descontos na compra do conteúdo, dada a força da barganha decorrente da demanda que concentram. Com isso, a pressão competitiva gerada pelos players de médio e pequeno porte fica limitada. Além disso, não há eficiências inerentes à operação, da forma em que foi apresentada.

209. Com vistas a limitar ao mínimo a intervenção no movimento de mercado observado, mas buscando assegurar que os consumidores finais do serviço de televisão por assinatura não suportem os custos do incremento de poder de mercado que se espera para a Newco, houve negociação de um Acordo em Controle de Concentração. Sublinho que, ao contrário do que argumentado em manifestações de terceiros intervenientes, não é, de nenhuma forma, escopo ou efeito do remédio negociado regular de forma geral segmentos sob competência da Anatel ou da Ancine. $\mathrm{O}$ arranjo conseguido implica apenas em obrigações que vinculam unicamente as Requerentes e condicionam a Newco, porque elaboradas única e exclusivamente para os casos concretos, de modo a controlar potenciais efeitos deletérios sob o interessado último na tutela do CADE: o consumidor final. A generalização e ampliação dos remédios negociados neste ACC podem implicar em expressivos prejuízos concorrenciais não calculados por essa agência antitruste. 


\section{II.10. Da proposta de Acordo em Controle de Concentração - ACC}

210. Com vistas a ajustar as preocupações concorrenciais ao diagnóstico anteriormente descrito, foi negociada proposta de Acordo em Controle de Concentração estruturado nos seguintes eixos:

i. Estabelecimento dos objetos da Newco, alguns deles com obrigações assumidas perante o CADE, a fim de melhorar as condições concorrências no mercado: (i) criação, produção e geração de conteúdo audiovisual para diferentes meios de comunicação, (ii) intermediação e agenciamento de conteúdo destinados à televisão por assinatura, (iii) prestação de serviços de assessoria de marketing e vendas em geral, (iv) representação publicitária e/ou venda de publicidade para os canais criados e/ou programados, (v) intermediação e representação para distribuição e venda de sinais de televisão para qualquer meio de distribuição e (vi) participação em outras sociedades;

ii. Estabelecimento de prazo para a existência da Newco, tendo em conta que a regra do retransmission consente é recente no Brasil, bem como que o mercado é muito dinâmico, de modo que pode ser útil nova avaliação sobre o funcionamento da empresa pelo CADE, considerando os efeitos da operação no mercado;

iii. Obrigação de investimento conjunto das Requerentes por meio da Newco, com integração econômica relevante orientada ao desenvolvimento conjunto de produtos e serviços para televisão paga e outras mídias, de modo que haja potencial para uma melhoria da qualidade do conteúdo já ofertado no mercado;

iv. Obrigação de investimentos individuais pelas Requerentes, tendo em vista o aprimoramento de conteúdo, com geração de externalidades positivas para telespectadores não assinantes de TV por assinatura, conforme plano de negócios a ser aprovado pelo CADE;

v. Tratamento assimétrico que implique em subsídio a pequenos e médios operadores de SeAC, visando a redução de seus custos, de forma a permitir que rivalizem com as grandes operadoras, limitando a capacidade destas de imporem aumentos de preço;

vi. Facilitação para o monitoramento do acordo pelo CADE, aumentando a possibilidade de detecção de eventual descumprimento;

vii. Aplicação de penalidades em caso de descumprimento do acordo. 


\section{III.10.1. Do objeto social}

211. A Newco terá diversas atividades que compõem o objeto social, conforme cláusula 3.1.1:

3.1.1 As Compromissárias se comprometem a constituir a Newco com o seguinte objeto social:

(a) criação, produção e geração de todo o tipo de conteúdo audiovisual, para todos os meios de comunicação;

(b) a intermediação e o agenciamento de conteúdos destinados à televisão por assinatura, independentemente da tecnologia;

(c) a prestação de serviços de assessoria de marketing e vendas em geral, incluindo a colocação de produtos, mediação no campo da propaganda e da publicidade, a compra, a venda, a veiculação e a divulgação, em televisão por assinatura e outros meios de comunicação, excetuando-se a televisão aberta, de material e espaço publicitário, bem como a elaboração de relatórios, pesquisas e estudos relativos a preferência pública e a métodos de organizações;

(d) a representação publicitária elou a venda de publicidade para os canais que venham a ser criados para televisão por assinatura elou programados pela Newco, incluindo faturamento e cobrança da publicidade vendida;

(e) a intermediação e a representação para distribuição e venda de sinais de televisão aberta elou por assinatura às Operadoras de Serviço de Acesso Condicionado, elou para exibição em quaisquer plataformas de distribuição no Brasil e no exterior.

(f) a participação em outras sociedades, como sócia ou acionista, no país ou no exterior.

212. Sobre essa cláusula vale ressaltar as atividades constantes na letra “a”, visto que as Requerentes se comprometerão, por meio do ACC, a obrigações relevantes, especialmente com a aplicação de percentual significativo de suas receitas no desenvolvimento de produtos e serviços para televisão por assinatura e outras mídias. Considerando investimentos individuais e em conjunto, detalhados a seguir, elas investirão percentuais da Receita Líquida de licenciamento nos valores totais de [acesso restrito ao CADE e Requerentes], deixando clara a ancilaridade das atividades de venda de produtos pela joint venture previstas na letra " $\mathrm{e}$ ". Ressalte-se que tais obrigações podem gerar eficiências compensatórias, em relação às operadoras de TV por assinatura 
líderes, e/ou mitigar os problemas apropriadamente enxergados pela Conselheira Relatora, conforme explicado a seguir.

213. Para tanto, as Requerentes se comprometem a enviar ao CADE um plano de negócios e relatórios anuais, conforme cláusulas 3.3.3 e 3.3.4 do ACC:

3.3.3 As Compromissárias se comprometem a apresentar ao CADE plano de negócio para o desenvolvimento e implementação dos Novos Conteúdos Conjuntos em até 06 (seis) meses contados da assinatura do primeiro contrato de licenciamento de canais de programação para televisão aberta com uma das Grandes Operadoras. Este plano de negócios deverá contemplar as eficiências específicas da Operação tratadas neste ACC e apresentar detalhadamente metas de investimento, prazos e alocação de recursos.

3.3.4 As Compromissárias se comprometem a enviar anualmente, até o dia 31 de maio do ano subsequente ao ano fiscal, relatório conjunto ao CADE discriminando (i) os investimentos realizados e programados em Novos Conteúdos Conjuntos e Novas Plataformas de Distribuição, o valor investido e o valor acumulado para investimento em ano(s) subsequente(s), (ii) os contratos, aditamentos, renovações ou rescisões que foram assinados celebrados com as Operadoras, e (iii) a conformidade com a forma de cobrança por sinais de canais de Televisão Aberta disposta neste ACC, devendo essas informações ser atestadas por auditoria independente previamente contratada à custa das Compromissárias ou da Newco, de acordo com a metodologia detalhada no Anexo I.

214. Destaque-se que a reprovação de operações é medida extrema no direito concorrencial, ocorrendo apenas quando não é possível encontrar soluções que alinhem o interesse público com o interesse privado. A operação inicialmente apresentada não tinha qualquer eficiência, mas com as obrigações assumidas pelas Compromissárias, houve uma mudança significativa dos efeitos finais da operação. Nesse sentido, passou a haver significativas eficiências de diferentes tipos, tanto no âmbito da própria $J V$ quanto na estrutura do mercado, de modo que há ganhos líquidos para o consumidor final, justificando a aprovação da operação. Desse modo, a intermediação e representação para distribuição e venda de sinais às operadoras passaram a ser ancilares em relação ao conjunto da operação. 


\section{III.10.2. Do prazo}

215. Em que pese os ganhos potenciais da operação para a sociedade e para os consumidores, verifica-se que o negócio de televisão passa por fase de profundas transformações, sendo uma delas a possibilidade de cobrança pelo uso do sinal das emissoras por parte das operadoras de televisão por assinatura. Por conta das incertezas que caracterizam mercados em mudança, optou-se por se ajustar um prazo para a existência da Newco, bem como para a vigência do $\mathrm{ACC}$, conforme se segue:

3.2.1 As Compromissárias se comprometem a constituir a Newco com prazo de duração de 06 (seis) anos, a contar do momento em que a Newco celebrar o primeiro contrato de licenciamento de canais de TV aberta com uma Grande Operadora.

[...]

6.1 Este ACC é vinculativo ao CADE, às Compromissárias e aos seus sucessores legais e permanecerá em vigor até o fim do prazo de duração da Newco.

216. Reconheço que a formação de novas empresas por prazo determinado tem seus pontos negativos, bem como não é um remédio comumente utilizado na teoria e na prática antitruste, mas também há de se reconhecer os pontos positivos. Nesse sentido, a fixação de prazo dará ao CADE oportunidade de analisar a evolução do mercado e os impactos do remédio consensuado. Se a experiência tiver apresentado resultados negativos, o novo Conselho terá dados suficientes para corrigir os erros e manter os efeitos positivos da operação, se for o caso.

217. Ressalte-se que as Requerentes aceitaram o acordo nesses termos, ainda que não fosse o desejo delas. Então, se elas o aceitaram tal como aqui apresentado, não cabe uma crítica do ponto de vista individual delas. Tratase de risco do negócio, e elas optaram por assumi-lo. Já do ponto de vista público, por todo o exposto, esperam-se efeitos líquidos positivos para a sociedade, mas em caso de isso não ser observado, o CADE poderá apresentar novos remédios após verificados os efeitos concretos da operação. 


\section{III.10.3. Do investimento conjunto}

218. Conforme previsto na cláusula 3.3, as Requerentes assumem obrigação de fazer investimentos conjuntos, por meio da JV, nos seguintes termos:

3.3.1 As Compromissárias se comprometem a reter parcela equivalente a [acesso restrito ao CADE e Requerentes] da RLL anual da Newco para investimentos conjuntos em:

a) análise de projetos de produção, geração e distribuição de conteúdo voltado ao mercado de televisão por assinatura;

b) criação, produção, agregação e distribuição de Novos Conteúdos Conjuntos; $e$

c) criação de Novas Plataformas de Distribuição.

219. Quanto ao conteúdo, ele deverá ser comercializado preferencialmente junto às operadoras, seja em pacote com os canais de televisão aberta, seja separadamente, ou ainda por meio de programadoras (cláusula 3.3.2). De qualquer forma, o CADE acompanhará o cumprimento dessas obrigações por meio do acesso ao plano de negócios e relatórios anuais, estes atestados por auditoria independente.

220. Espera-se com isso a potencial criação de eficiências, tais como economias de escala e sinergias decorrentes de eventuais ativos complementares das emissoras. Embora sejam emissoras com porte significativo, há uma dominação do mercado pela Globo, que possui uma estrutura e uma audiência significativamente maior do que a das Requerentes, a ponto de a rivalidade delas com a Globo ser limitada. Investimentos conjuntos, aproveitando a expertise das diferentes Requerentes, possibilitam a criação de novos produtos e serviços, aumentando a pressão competitiva no setor de entretenimento, beneficiando, de forma bastante disseminada, a sociedade brasileira.

\section{III.10.4. Dos investimentos individuais}

221. A cláusula 3.4.1 implica em obrigação de investimentos individuais, que serão realizados utilizando-se de percentuais [acesso restrito ao CADE e Requerentes] significativos da Receita Líquida de licenciamento, a fim de haver um aprimoramento do conteúdo produzido, conforme se segue: 
3.4.1 As Compromissárias se comprometem a reter parcela da RLL anual da Newco distribuída a cada Compromissária na forma do seu Contrato Social/Acordo de Quotistas, em percentuais [acesso restrito ao CADE e Requerentes] e até o final do prazo de duração da Newco, para investimentos em Aprimoramento de Conteúdo, englobando:

a) prospecção de novos projetos e análise de viabilidade;

b) desenvolvimento de conteúdo de teledramaturgia, entretenimento e jornalismo, quer seja em programas inteiros ou em parte (quadros), sejam de produção própria, em coprodução ou licenciado de terceiros; $e$

c) investimento em infraestrutura de produção de conteúdo. [...]

[...]

3.4.3 As Compromissárias se comprometem a enviar anualmente, até o dia 31 de maio do ano subsequente ao ano fiscal, relatórios individuais ao CADE discriminando os investimentos realizados e programados em Aprimoramento de Conteúdo, o valor investido proveniente da Newco e o valor acumulado para investimento em ano(s) subsequente(s), devendo essas informações se atestadas por auditoria independente previamente contratada à custa das Compromissárias, de acordo com a metodologia detalhada no Anexo I.

222. Tal como objetivado no investimento conjunto, espera-se com tais obrigações um aumento da capacidade delas de concorrer no mercado, principalmente com a empresa líder, gerando inclusive externalidades positivas para o consumidor sem acesso à TV por assinatura, geralmente de renda mais baixa. Entende-se que, embora externalidade positiva seja uma falha de mercado, deve-se considerar não apenas o ganho para a população de mais baixa renda, mas também um ciclo virtuoso decorrente da provável melhoria do conteúdo e do possível aumento da audiência, tanto na televisão aberta quanto na fechada, em função dos novos investimentos. Nesse sentido, esse ciclo virtuoso decorreria de que mais telespectadores tendem a gerar mais renda para as emissoras e, possivelmente, também para as operadoras de televisão por assinatura, aumentando os investimentos e dinamizando mais o setor.

223. Destaque-se que assim como em relação aos investimentos conjuntos, haverá o monitoramento do CADE por meio de acesso a relatórios anuais, pelo prazo de duração da JV, atestados por auditoria independente. As Requerentes terão que seguir um plano de negócios, aprovado pelo CADE, que efetivamente aumente a rivalidade no setor, em benefício dos consumidores finais. 


\section{III.10.5. Do tratamento diferenciado para pequenas e médias operadoras}

224. Consta ainda do acordo condições de licenciamento de forma favorecida para operadoras médias e pequenas, sendo uma compensação aceita pelas Compromissárias, conforme se segue:

3.5.2 Para as Operadoras Médias, as Compromissárias se comprometem a cobrar, por Assinante, pelo licenciamento dos sinais de seus canais de televisão aberta, valor não superior à média dos preços médios por Assinante efetivamente aplicados a cada uma das Grandes Operadoras, em bases de nação mais favorecida (Most Favored Nation - "MFN").

3.5.2.1 A forma de precificação descrita nesta cláusula 3.5.2 corresponde à seguinte fórmula: $V \leq(P 1+\ldots+P n) / n$. Sendo $V$ o valor, por Assinante, do licenciamento dos sinais de canais de televisão aberta para Operadoras Médias; P1 = o preço médio por Assinante efetivamente aplicado a contrato da Newco com Grande Operadora 1; $\mathrm{Pn}=$ o preço médio por Assinante efetivamente aplicado a contrato com Grande Operadora $n$.

3.5.3 Para as Pequenas Operadoras as Compromissárias se comprometem a ceder de forma gratuita e não onerosa os sinais de seus canais de televisão aberta.

3.5.3.1 É vedado às Compromissárias impor qualquer limitação, restrição, ônus ou óbice à recepção direta (através do SeAC) ou indireta (mediante a captação do sinal digital terrestre do Sistema Brasileiro de Televisão Digital Terrestre - SBTVD-T) dos sinais digitais dos canais pelas Pequenas Operadoras elou por seus assinantes.

3.5.3.2 É vedado às Compromissárias impor qualquer limitação, restrição, ônus ou óbice (i) à tecnologia elou equipamentos utilizados pelas Pequenas Operadoras para distribuição dos sinais digitais dos canais de televisão para seus assinantes, elou (ii) aos modelos de contratação e divulgação da distribuição dos canais adotado pelas Pequenas Operadoras com seus assinantes, na forma da lei.

225. Essas cláusulas se justificam em virtude de as grandes operadoras possuírem maior poder de barganha na negociação com as emissoras, quando comparadas com as médias e pequenas operadoras. Essa assimetria de poder colaborar para o elevado nível de concentração no mercado de TV por 
assinatura no país, com a consequente restrição concorrencial, o que tende a não ser benéfico para os consumidores.

226. Como se depreende das cláusulas citadas, com o acordo, as operadoras médias, com número nacional de assinantes igual a $5 \%$ e menor que $20 \%$, serão beneficiadas pelo preço dos sinais de televisão aberta da Newco não superior ao preço médio por assinante efetivamente aplicado para as grandes operadoras, as que possuem número nacional de assinantes superior a $20 \%$ do total apurado no país. Quanto às pequenas operadoras, com número nacional de assinantes igual ou inferior a 5\% e não pertencentes a grandes grupos econômicos, os sinais dos canais de televisão aberta serão cedidos de forma gratuita e não onerosa, sem que a Newco possa colocar restrições ou dificuldades para que tal acesso se concretize.

227. O objetivo é permitir que essa franja possa gerar uma pressão competitiva sobre as líderes, inibindo o exercício do poder de mercado destas. Se no direito concorrencial há uma clara preocupação com o bem-estar do consumidor, o acordo estimula a competição no mercado de TV por assinatura, colaborando para um aumento da diversidade de opções à disposição do consumidor final.

228. Ressalte-se que essa preocupação com o tratamento dado às operadoras de menor porte, incluindo potenciais entrantes, é uma preocupação apresentada também pela Conselheira Relatora e pela SuperintendênciaGeral.

\section{III.10.6. Do monitoramento}

229. A cláusula 4 trata do monitoramento do acordo, utilizando-se de alguns dos meios usualmente utilizados pelo CADE para tal finalidade. Assim, durante a vigência do ACC, o Conselho terá diferentes instrumentos de monitoramento, conforme se segue:

4.2 Nos termos do art. 9ํ, XVIII, da Lei 12.529/2011, durante o prazo de vigência deste ACC, o CADE poderá, a qualquer momento, (i) exigir que as Compromissárias apresentem dados e informações que julgar necessários relativos às obrigações previstas neste ACC, e (ii) solicitar manifestação das agências reguladoras pertinentes sobre a compatibilidade dos contratos celebrados pela Newco e dos investimentos realizados pelas Compromissárias com as leis e regulamentos aplicáveis. 
[...]

4.4 Sem prejuízo do disposto no art. 13, inciso VI, letra "c" da Lei $n^{-}$12.529/11, as Compromissárias se comprometem a manter política de portas abertas ("open door policy"), reconhecendo o direito de o CADE, por meio da Superintendência-Geral, realizar inspeções na Newco.

4.5 As Compromissárias se obrigam a prestar irrestrita colaboração técnica às autoridades concorrenciais do CADE, conforme a Lei 12.529/2011, promovendo, sempre que solicitados, esclarecimentos sobre sua atuação em televisão aberta e por assinatura.

230. Considerando, pois, o acesso a dados e informações, a colaboração técnica e o open door policy, assim como o acesso ao plano de negócios e aos relatórios anuais, o CADE terá ampla possibilidade de verificar se está havendo o adimplemento do contrato. Contudo, ainda que a Superintendência-Geral opte por não monitorar detalhadamente o cumprimento do contrato, tendo em vista a restrição de recursos materiais, financeiros e de pessoal, a mera previsão dessas medidas, associadas a eventuais informações de clientes e concorrentes, gera um risco significativo de detecção, pelo CADE, de descumprimento do acordo. Pode-se concluir, pois, que eventuais descumprimentos sejam bastante improváveis.

\section{III.10.7. Das penalidades}

231. No caso de verificação de algum descumprimento, poderão ser aplicadas as penalidades previstas na cláusula 5, das quais se destacam:

6.1 O descumprimento da obrigação conjunta das Compromissárias de envio de relatório conjunto anual ao CADE [...] ensejará a aplicação de multa diária no valor de $R \$ 50.000$ (cinquenta mil reais) por evento de descumprimento, limitada ao máximo de 30 (trinta) dias, [...]

6.2 O descumprimento da obrigação conjunta das Compromissárias de envio de (a) cópia dos atos constitutivos da Newco devidamente registrados em junta comercial, (b) plano de negócio relativo aos Novos Conteúdos Conjuntos que contemple as eficiências específicas da Operação tratadas neste ACC e apresente detalhadamente metas de investimento, prazos e alocação de recursos, ou (c) relatório de auditoria independente acerca de contratos, 
aditamento, renovação ou rescisão celebrados com as Operadoras, bem como todas as informações e ou documentos requeridos pelo CADE para fins de monitoramento deste ACC, ensejará a aplicação de multa diária no valor de $R \$ 50.000$ (cinquenta mil reais) por evento de descumprimento, limitada ao máximo de 30 (trinta) dias, por evento de descumprimento, a incidir a partir da data do descumprimento até a data em que a obrigação efetivamente for cumprida.

$[\ldots]$

$6.4 \mathrm{O}$ descumprimento da obrigação individual de cada Compromissária de envio de relatório individual anual ao CADE discriminando os investimentos realizados e programados em Aprimoramento de Conteúdo, previsto na cláusula 3.4.3, ensejará a aplicação de multa diária no valor de $R \$ 50.000,00$ (cinquenta mil reais) por evento de descumprimento, a incidir a partir da data do descumprimento até a data em que a obrigação efetivamente for cumprida, a ser paga individualmente pela Compromissária em mora. [grifo nosso]

232. Vê-se que o atraso nas obrigações implica em multa diária, podendo alcançar R\$ 1,5 milhão por evento de descumprimento, a ser revertida para o Fundo Nacional de Direitos Difusos. Em caso de continuidade do descumprimento, garantido o direito ao contraditório e à ampla defesa, a operação será reprovada, sem prejuízo das multas aplicadas. Assim, considerando o elevado risco de detecção de descumprimento do acordo, bem como os valores significativos a que podem chegar as multas e à possibilidade de revisão do acordo, entendo ser pouco provável que venha a ocorrer o seu descumprimento.

\section{III.10.8. Das alterações contratuais}

233. Por fim, ressalto as possibilidades de alteração contratual, nos seguintes termos:

8.1 O CADE poderá, em resposta a um pedido das Compromissárias ou por sua própria iniciativa, conceder prorrogação dos prazos previstos neste ACC.

8.2 Quando as Compromissárias solicitarem a prorrogação de prazos, elas deverão protocolar pedido fundamentado ao CADE com antecedência mínima de 1 (um) mês antes do fim do respectivo prazo. Somente em circunstâncias 
excepcionais poderão as Compromissárias requerer prorrogação durante o período de 1 (um) mês que anteceder o fim do respectivo prazo.

8.3 O CADE poderá, em resposta a um pedido justificado das Compromissárias, excluir, alterar ou substituir uma ou mais das obrigações previstas neste ACC.

234. Essas cláusulas se justificam principalmente pelo extremo dinamismo desse mercado, de forma que não seria justificável manter prazos ou obrigações que se mostrarem, no futuro, indesejáveis tanto do ponto de vista das empresas quanto do ponto de vista social.

\section{III.10.9. Das considerações finais sobre o ACC}

235. Considerando o exposto no voto, e principalmente as cláusulas do contrato, entendo que se conseguiu preservar o interesse público, em especial dos consumidores, sem inibir a liberdade de associação, a qual apresenta, nos termos do ACC, baixo potencial anticompetitivo, bem como eficiências decorrentes da união de esforços das Requerentes.

236. Quando considerada a atual estrutura de mercado no setor, com elevada concentração tanto no lado das emissoras quanto no de operadoras de televisão por assinatura, os efeitos esperados do ACC passam a ser um aumento da pressão competitiva, o que entendo ser um objetivo desse Conselho, tendo em vista os benefícios sociais gerados.

\section{Dispositivo}

237. Ante todo o exposto, concluo que não foi identificado qualquer potencial de efeito adverso da possibilidade de produção, por SBT, Record e Rede TV!, por meio da Newco ou não, de conteúdo audiovisual. Tampouco foi verificado qualquer risco anticompetitivo associado à possiblidade de prestação de serviços de assessoria e marketing, uma vez que foi vedado em contrato social o desenvolvimento deste tipo de atividade envolvendo televisão aberta.

238. Foi constatada, porém, uma possibilidade, ainda que pequena, de risco anticoncorrencial associado à possibilidade de coordenação de venda de sinal de televisão aberta para operador de televisão por assinatura. Entende-se que as condições pactuadas em ACC endereçam adequadamente 
tais preocupações e por isso voto pela rejeição dos pedidos recursais e aprovação da operação com restrições.

239. É o voto.

Brasília, 11 de maio de 2016.

\section{[assinatura eletrônica] \\ ALEXANDRE CORDEIRO MACEDO}

Conselheiro 